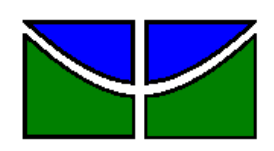

Universidade de Brasília

Faculdade de Economia, Administração e Contabilidade

Departamento de Administração

CAMILA DA SILVA MILHOMEM

\title{
GERAÇÃO DE EFICIÊNCIAS OPERACIONAIS A PARTIR DA ESTRATÉGIA DE FUSÃO E AQUISIÇÃO
}

Brasília - DF 


\section{CAMILA DA SILVA MILHOMEM}

\section{GERAÇÃO DE EFICIÊNCIAS OPERACIONAIS A PARTIR DA ESTRATÉGIA DE FUSÃO E AQUISIÇÃO}

Monografia apresentada ao

Departamento de Administração como requisito parcial à obtenção do título de Bacharel em Administração.

Professor Orientador: Dr. Valmir Emil Hoffmann

Brasília - DF 
Milhomem, Camila da Silva.

Geração de eficiências operacionais a partir da estratégia de fusão e aquisição / Camila da Silva Milhomem - Brasília, 2011.

$80 \mathrm{f}$. : il.

Monografia (bacharelado) - Universidade de Brasília, Departamento de Administração, 2011.

Orientador: Prof. Dr. Valmir Emil Hoffmann, Departamento de Administração.

1. Fusão. 2. Aquisição. 3. Eficiência operacional I. Título. 


\title{
CAMILA DA SILVA MILHOMEM
}

\section{GERAÇÃO DE EFICIÊNCIAS OPERACIONAIS A PARTIR DA ESTRATÉGIA DE FUSÃO E AQUISIÇÃO}

\begin{abstract}
A Comissão Examinadora, abaixo identificada, aprova o Trabalho de Conclusão do Curso de Administração da Universidade de Brasília da aluna
\end{abstract}

\section{Camila da Silva Milhomem}

\author{
Dr. Valmir Emil Hoffmann \\ Professor-Orientador \\ Dr. José Márcio Carvalho \\ Professor-Examinador \\ Dr. Eduardo Raupp de Vargas \\ Professor-Examinador
}




\section{AGRADECIMENTOS}

A todos os que entenderam minhas ausências e aceitaram

minhas omissões. Aos que compartilharam comigo todos os momentos.

Aos que inspiram minhas ideias e permitem ter as suas inspiradas por mim.

À minha querida família, simplesmente, por tudo. 
"As duas coisas mais envolventes [...] são tornar familiares as coisas novas e tornar novas as coisas familiares" (Samuel Johnson). 


\section{RESUMO}

A atual ambiente concorrencial exige das empresas uma postura que vise sustentar sua posição no mercado e aumentar seu market share. Nesse contexto, as fusões e aquisições surgem como uma alternativa. Entretanto, não deve ser vista como uma solução simples, pois constitui um processo que envolve muitos riscos e ainda não há consenso na literatura se eles são capazes de eficiências operacionais. Visando preencher essa lacuna, o presente estudo analisou a geração de eficiências operacionais decorrentes dos processos de fusão e aquisição de empresas por meio dos atos de concentração ocorridos entre 2002 e 2008. Com base na variação dos indicadores financeiros, utilizaram-se a análise documental quantitativa e a análise de cluster, a fim de mensurar o desempenho financeiro das empresas da amostra bem como analisar se há padrão de agrupamento entre elas. Pela análise, concluiuse que as empresas podem obter economia de escala, todavia apresentam ineficiências administrativas quando da reestruturação. Concluiu-se ainda que as empresas têm dificuldade em verificar e quantificar os incrementos de eficiência, em parte porque as informações necessárias se referem a eventos futuros.

Palavras-chave: Fusão. Aquisição. Eficiência operacional 


\section{LISTA DE ABREVIATURAS E SIGLAS}

BID - Banco Interamericano de Desenvolvimento

CADE - Conselho Administrativo de Defesa Econômica

CMV - Custo da Mercadoria Vendida

DA - Despesa Administrativa

F\&A - Fusão e Aquisição

IBGC - Instituto Brasileiro de Governança Corporativa

MB - Margem Bruta

ML - Margem Líquida

OCDE - Organização para a Cooperação e o Desenvolvimento Econômico

$\mathbf{R L}$ - Receita Líquida

SBDC - Sistema Brasileiro de Defesa da Concorrência

SDE - Secretaria de Direito Econômico

SEAE - Secretaria de Acompanhamento Econômico 


\section{LISTA DE FIGURAS}

Figura 1 - Linha do tempo relativa à $2^{\mathrm{a}}$ perspectiva ......................................... 41

Figura 2 - Dendograma obtido na análise de cluster..........................................56

\section{LISTA DE GRÁFICOS}

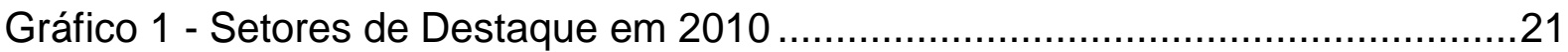

Gráfico 2 - Evolução anual do número de transações $(1994-2009)$.......................23

\section{LISTA DE QUADROS}

Quadro 1 - Tipos e motivos da ocorrência de F\&A............................................26

Quadro 2 - Amostra da população ............................................................. 38

Quadro 3 - Indicadores financeiros utilizados...............................................40

Quadro 4 - Motivação x Eficiência operacional obtida....................................60 


\section{LISTA DE TABELAS}

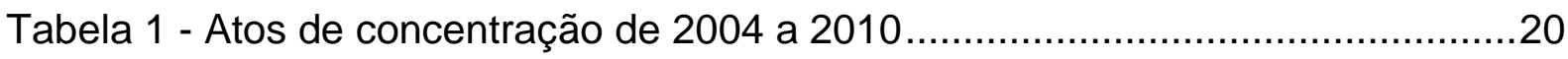

Tabela 2 - Empresas que apresentaram melhora no desempenho do CMV/RL .......44

Tabela 3 - Empresas que apresentaram piora no desempenho do CMV/RL ............45

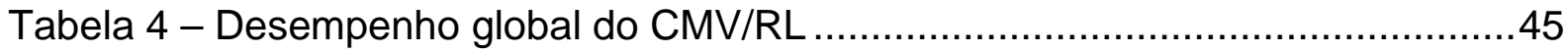

Tabela 5 - Empresas que apresentaram melhora no desempenho da DA/RL ..........47

Tabela 6 - Empresas que apresentaram piora no desempenho de DA/RL ..............48

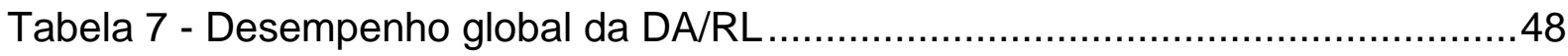

Tabela 8 - Empresas que apresentaram melhora no desempenho da MB ..............50

Tabela 9 - Empresas que apresentaram piora no desempenho da MB ...................51

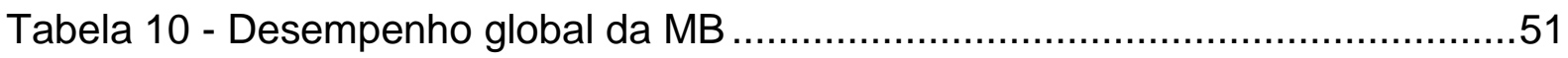

Tabela 11 - Empresas que apresentaram melhora no desempenho da ML..............53

Tabela 12 - Empresas que apresentaram piora no desempenho da ML..................54

Tabela 13 - Desempenho global da ML ……………......................................

Tabela 14 - Valores médios dos grupos em relação ao desempenho de cada variável 56

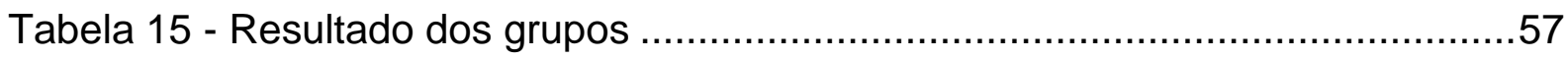




\section{SUMÁRIO}

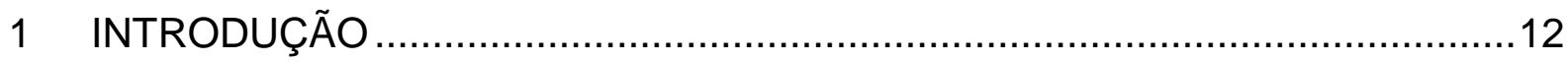

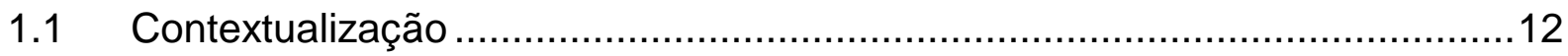

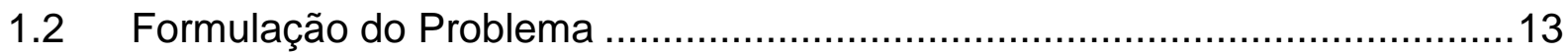

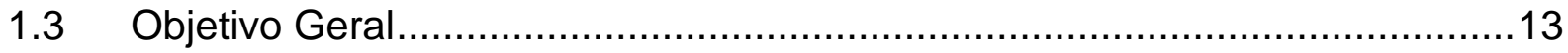

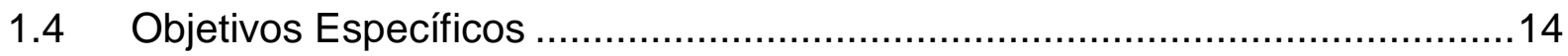

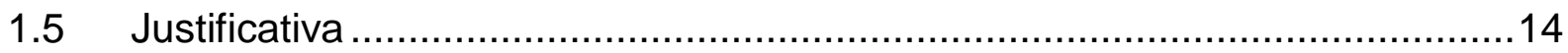

1.6 Estrutura e Organização do Trabalho ....................................................15

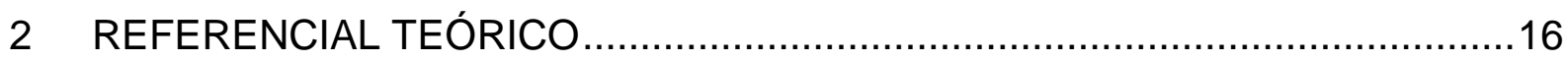

2.1 Sistema Brasileiro de Defesa da Concorrência ..........................................16

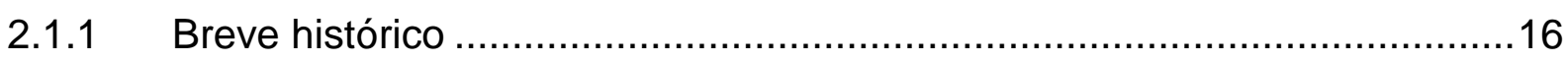

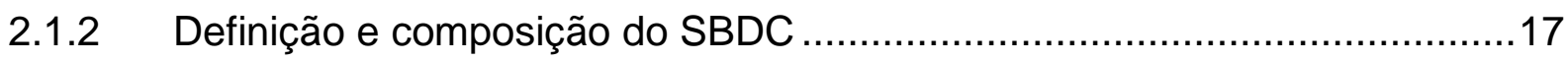

2.1.3 Atos de concentração ……………………...................................18

2.1.3.1 Critérios para notificação ao SBDC......................................................19

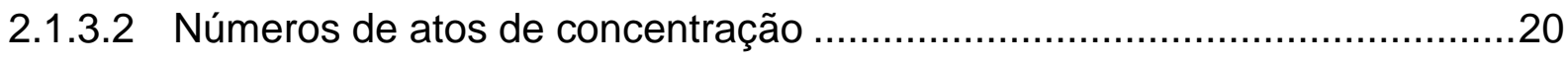

2.2 A Estratégia de Fusão e Aquisição ........................................................21

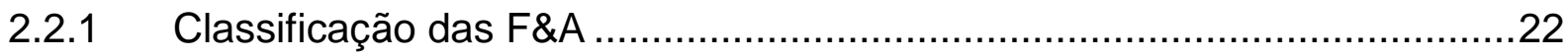

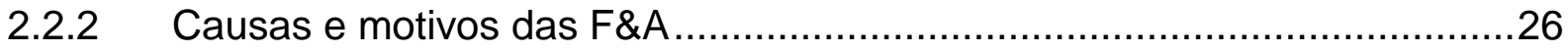

2.2.3 Sinergias e eficiências operacionais ....................................................30

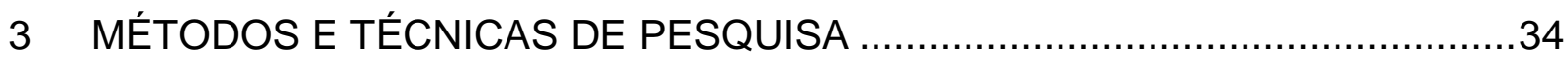

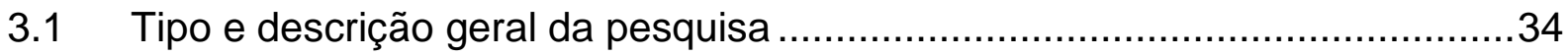

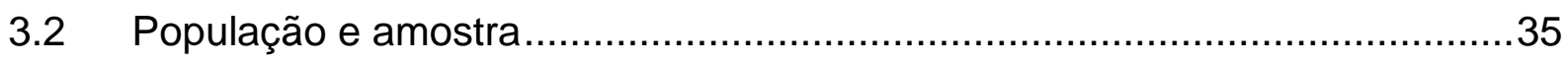

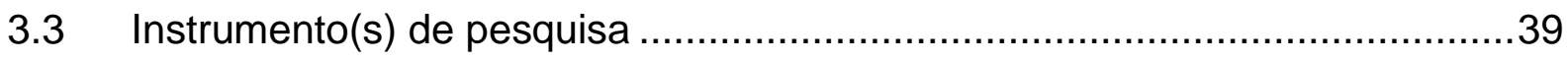

3.4 Procedimentos de coleta e análise de dados .............................................40

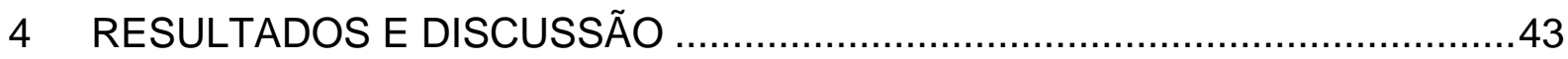

4.1 Eficiências operacionais obtidas com base no desempenho do CMV/RL ......43 
4.2 Eficiências operacionais obtidas com base no desempenho da $\mathrm{DA} / \mathrm{RL}$........46

4.3 Eficiências operacionais obtidas com base no desempenho da MB ............49

4.4 Eficiências operacionais obtidas com base no desempenho da ML.............52

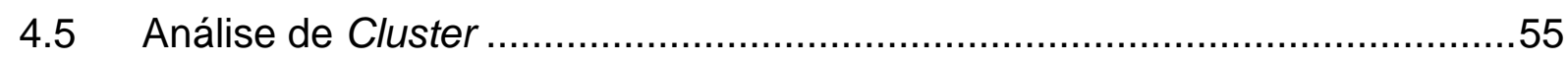

4.6 Motivação para adoção da estratégia de F\&A x sinergias observadas ..........58

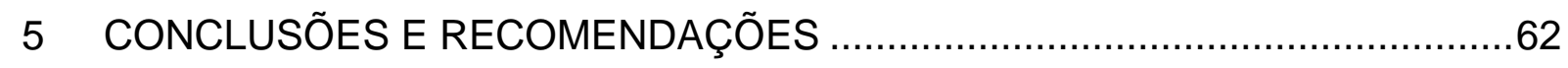

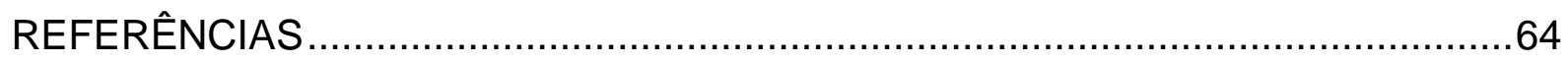

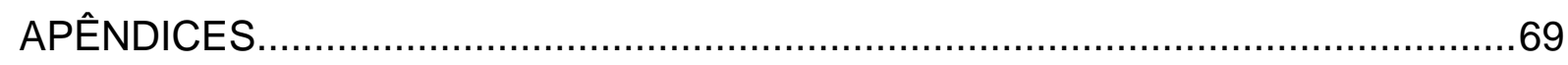

Apêndice A - Dados financeiros das empresas da amostra ...............................69

Apêndice B - Desempenho dos indicadores financeiros das empresas da amostra 74 


\section{INTRODUÇÃO}

\subsection{Contextualização}

A partir dos anos 1990, as empresas têm sofrido com o acirramento da concorrência, uma vez que o mundo tornou-se um só mercado em consequência dos diversos processos de abertura comercial. Desde então, as empresas buscam o ingresso em novos mercados e o aumento do market share naqueles mercados em que já atuam (SUEN;KIMURA, 1997).

A expansão empresarial pode ocorrer de várias formas, dependendo das estratégias adotadas pelas empresas. Cabe destacar, entre essas estratégias, o investimento em novas plantas, em que a empresa, por si só, busca o ingresso em novos mercados, o aumento de seu market share e os processos de fusão e aquisição, nos quais as empresas crescem através de outras, aproveitando a posição daquelas em determinado mercado.

Os processos de fusão e aquisição são vistos, muitas vezes, como excelente alternativa, pois são capazes de poupar esforços e investimentos para a empresa, como a instalação de nova planta, ou pesquisa do mercado consumidor, ou desenvolvimento em novos produtos, ou aprendizado (OLIVEIRA; ROCHA, 2006; MIRANDA; MARTINS, 2000). Entretanto, trazem consigo também alguns riscos, como a adaptação da cultura organizacional das empresas envolvidas, efetiva integração dos processos da empresa e transferência de conhecimento. Fusão e aquisição de empresa podem representar excelente oportunidade para expandir e consolidar uma posição mais relevante no mercado, mas não devem, de forma alguma, serem vistas como alternativa simples para isso, pois trazem consigo muitos riscos embutidos (OLIVEIRA; FORTE; RAGÃO, 2007).

Os processos de F\&A de empresas objetivam o acesso a novos mercados, a aquisição de tecnologia e conhecimento, o aumento do market share, a proteção 
contra concorrentes e possíveis aquisições indesejadas, a diminuição de custos, a substituição de administração eficiente, sinergias e eficiências operacionais, a diminuição de risco operacional e financeiro ou, simplesmente, a sobrevivência das empresas. (CAMARGOS; BARBOSA, 2005a).

\subsection{Formulação do Problema}

Os processos de F\&A não são recentes, mas têm se tornado cada vez mais significativos e numerosos, não só no Brasil como no mundo. Em 2009 foram analisados 457 processos de atos de concentração - fusão, aquisição e incorporação - pelo Sistema Brasileiro de Defesa da Concorrência (SBDC); de janeiro a outubro de 2010, foram analisados 483. Alguns desses processos envolvem empresas de menor porte e, por isso, nem sequer são divulgados pela mídia convencional. Outros, porém, são bastante significativos, como Sadia e Perdigão, Nossa Caixa e Banco do Brasil, Casas Bahia e Pão de Açúcar, isso para citar apenas alguns exemplos que podem causar impactos no consumidor final, sobretudo pela decorrente concentração de mercado.

Em virtude dessa possível concentração de mercado, para ser aprovado pelo SBDC, dependendo de sua magnitude, um ato de concentração deve provar que é capaz de gerar eficiências operacionais que não podem ser obtidas de outra forma em um período inferior a dois anos, sejam elas economia de escala, de escopo ou introdução de nova tecnologia. Nesse sentido, o problema de pesquisa do presente estudo desenvolve-se acerca da seguinte questão: quais eficiências operacionais um processo de F\&A é capaz de gerar para as empresas envolvidas?

\subsection{Objetivo Geral}

Analisar as eficiências operacionais decorrentes dos processos de F\&A de empresas ocorridos entre os anos de 2000 e 2010. 


\subsection{Objetivos Específicos}

a) identificar as motivações das empresas para a adoção da estratégia de F\&A de empresas;

b) identificar as eficiências relacionadas ao custo da mercadoria vendida;

c) identificar as eficiências relacionadas à despesa administrativa;

d) identificar as eficiências relacionadas à margem bruta;

e) identificar as eficiências relacionadas à margem líquida;

f) identificar as eficiências operacionais e financeiras percebidas em processos de F\&A já ocorridos.

\subsection{Justificativa}

A literatura acerca da geração de sinergias em processos de F\&A de empresas ainda é muito contraditória. Existem pesquisas que comprovam ser possível gerar sinergias (CAMARGOS; BARBOSA, 2009; NGUYEN; OLLINGER, 2006; CAMARGOS; BARBOSA, 2005b; ZILBER et al., 2002; PASIN; MATIAS, 2001; PASIN et al., 1999) enquanto outras comprovam que o resultado das empresas envolvidas se manteve ou piorou após passarem pelo processo de $F \& A$, quando comparadas à média do mercado (ROCHA et al.; 2001; DICKERSON et al., 1997; RAVENSCRAFT; SCHERER, 1987).

Ainda diante dessa incerteza, observa-se que há cada vez mais casos ocorrendo, tanto no Brasil como no mundo. $\mathrm{E}$ as razões para isso são variadas, indo desde proteção contra concorrentes até substituição de administração ineficiente.

Uma motivação bastante recorrente para as empresas utilizarem esse tipo de estratégia são as sinergias e eficiências operacionais, seja pela ocorrência de economia de escala (diminuição de custos pelo aumento da produção), de escopo (quando duas ou mais empresas podem dividir ou usar conjuntamente bens não divisíveis, como maquinário ocioso) ou transferência de tecnologia. Entretanto, ainda não há consenso na literatura se os processos de fusão e aquisição efetivamente 
geram sinergias, tanto a curto quanto a longo prazo. Esse estudo, portanto, busca analisar se de fato há sinergias nesse processo de F\&A de empresas e até que ponto elas se perpetuam.

Dessa forma, pelo destaque atual do tema, o presente estudo busca desenvolver análise que traga um pouco mais de clareza sobre se os processos de $\mathrm{F} \& \mathrm{~A}$, apesar de todos os riscos, são vantajosos para as empresas envolvidas.

Os resultados, para comprovar se realmente há sinergias ou não, são relevantes tanto para a teoria, que ainda possui uma lacuna acerca desse conhecimento, quanto para a prática, pois pode nortear empresas, consumidores e governo a respeito dos reais benefícios de tal processo.

\subsection{Estrutura e Organização do Trabalho}

O presente estudo divide-se em seções, a saber: introdução, referencial teórico, métodos e técnicas de pesquisa, resultados e conclusão. Visando situar o leitor no tema abordado, o referencial teórico foi estruturado com base na definição e análise dos seguintes conceitos: SBDC, classificação das F\&A, causas e motivos das F\&A e sinergias e eficiências operacionais geradas pelo processo de F\&A.

A seção de métodos e técnicas de pesquisa apresenta as ferramentas utilizadas e a maneira como foram realizadas a coleta e a interpretação dos dados, que possibilitaram alcançar os resultados e conclusões do presente estudo. 


\section{REFERENCIAL TEÓRICO}

\subsection{Sistema Brasileiro de Defesa da Concorrência}

Para tratar o tema de F\&A de empresas, inicialmente é necessário compreender como a legislação brasileira se posiciona e assim vislumbrar a dimensão em que os processos de $F \& A$, e, consequentemente, o presente estudo estão inseridos.

Assim, esta seção objetiva descrever o SBDC com base nos seguintes aspectos: breve histórico, definição e composição do SBDC e atos de concentração, que são os temas relevantes para a análise deste estudo.

\subsubsection{Breve histórico}

As políticas econômicas do Brasil pós II Guerra Mundial se caracterizaram por forte intervenção governamental no mercado. A maior parte das grandes empresas do país era, portanto, de propriedade do Estado, que controlava os preços.

A primeira iniciativa de defesa da concorrência brasileira (Lei № 4.137/62) ocorreu em 1962 e criou o Conselho Administrativo de Defesa Econômica (Cade) órgão existente até hoje. Era competência do Cade impedir o abuso do poder econômico exercido pelo governo, o que contraditoriamente surtiu pouco efeito, pelo fato de a economia ser controlada de maneira rígida pelo Estado (OCDE; BID, 2010).

A desregulamentação da economia teve início em 1990, quando o então presidente da República, Fernando Collor de Melo, promoveu uma série de reformas econômicas, incluindo privatizações, desregulamentação e liberalização de preços. Nesse contexto, foi promulgada, em 1994, a Lei no 8.884 , ainda em vigor e que trata da defesa da concorrência. Portanto, a era da moderna política de concorrência 
começou em meados dos anos 90, coincidentemente com a transição do país para uma economia de mercado (OCDE;BID, 2010).

\subsubsection{Definição e composição do SBDC}

A política de concorrência, conforme previsto no artigo 173 , $\S 4$, da Constituição Brasileira, determina que "[a] lei reprimirá o abuso do poder econômico que vise à dominação dos mercados, à eliminação da concorrência e ao aumento arbitrário dos lucros" (CONSTITUIÇÃO FEDERAL, 2007, p. 52).

Consoante essa definição, Ozeml (2006) afirma que o propósito das leis antitruste e de F\&A de empresas é sustentar um ambiente competitivo e aumentar o bem-estar econômico e social. Dessa forma, devem ser analisadas com cautela, por causa dos impactos negativos que podem acarretar, sobretudo para o consumidor, operações que, entre outras consequências, provoquem elevação de preços, prejudiquem a inovação e diminuam o bem-estar da sociedade pela concentração de mercado e, por isso, afetem a oferta e a distribuição de produtos. Nesse sentido, Pereira (2004) afirma que "a concentração deve ser vista como uma ação que, mesmo quando não inviabiliza a concorrência, altera o nível de competição, prejudicando em última instância o consumidor." (PEREIRA, 2004, p. 39).

Em se tratando especificamente do Sistema Brasileiro de Defesa da Concorrência, a Lei de Defesa da Concorrência (8.884/94) criou os três órgãos que o compõem Secretaria de Direito Econômico (SDE), do Ministério da Justiça; Secretaria de Acompanhamento Econômico (SEAE), do Ministério da Fazenda; e Conselho Administrativo de Defesa Econômica, autarquia federal vinculada ao Ministério da Justiça. Esses órgãos, em conjunto, atuam como advogados da concorrência, tanto em casos de conduta (cartéis) quanto em atos de concentração (fusão, aquisição e incorporação de empresas). O presente trabalho analisará somente o SBDC no que tange a atos de concentração, uma vez que casos de conduta fogem ao escopo deste estudo. 


\subsubsection{Atos de concentração}

Na Lei 8.884, a previsão de controle dos atos de concentração encontra fundamento no artigo 54:

Os atos, sob qualquer forma manifestados, que possam limitar ou de toda forma prejudicar a livre concorrência, ou resultar na dominação de mercados relevantes de bens ou serviços, deverão ser submetidos à apreciação de Cade (OCDE, BID; 2010, p. 30, grifo da autora).

Dessa forma, o SBDC visa observar o princípio da livre concorrência, previsto no art. 170 da Constituição Federal e promover, assim, uma economia competitiva por meio da prevenção de atos que possam vir a prejudicar a concorrência. Isso é essencial, pois é ela que contribui para a oferta de produtos diversificados, para a competitividade nos preços, para a busca por inovação de produtos e para a qualidade dos serviços prestados.

Todavia, apesar da importância do SBDC em garantir a livre concorrência no mercado de modo a não prejudicar esses quesitos, seu objetivo maior deve ser garantir o bem estar social. Nesse sentido, o mercado oligopolista ou mesmo monopolista, dependendo do setor de atuação, torna-se necessário para garantir o porte e escala necessários para que a empresa possa atuar eficientemente, como é o caso do setor de tecnologia e inovação, devido aos altos investimentos necessários.

Para a análise dos atos de concentração submetidos ao SBDC, utiliza-se o Guia para Análise Econômica dos Atos de Concentração Horizontal, previsto na Portaria conjunta SEAE/SDE no 50 de 2001. Ele descreve cinco etapas, que devem ser seguidas no procedimento de análise: (1) definir os mercados relevantes de produto e geográfico, (2) determinar se a participação de mercado da nova empresa é suficientemente ampla para permitir o exercício do poder de mercado, (3) avaliar a probabilidade de exercer o poder de mercado após a concentração, (4) examinar as eficiências geradas pela operação e (5) avaliar o efeito líquido da operação sobre o bem-estar econômico. É importante destacar que o ônus de mostrar se o ato de concentração é benéfico recai sobre as requerentes, ou seja, as empresas envolvidas na transação (OCDE; BID, 2010). Os passos de análise do Guia são 
excludentes, ou seja, caso seja observado, já no primeiro passo, pela definição do mercado relevante, que a operação não é capaz de gerar efeitos anticoncorrenciais, a análise é interrompida nesse ponto, e não avança para os demais.

Observa-se que a análise das eficiências geradas pela operação, objeto de análise do presente estudo, situa-se no quarto e penúltimo passo, indicando que, se a análise chegar a esse ponto, as empresas envolvidas provavelmente exercerão poder de mercado e, assim, para a aprovação do ato, terá de haver eficiências operacionais que o justifiquem.

Portanto, caberá às requentes provar que a operação é capaz de gerar eficiências operacionais (de escala, de escopo ou de transferência de tecnologia) que não podem ser obtidas de outra forma em período inferior a dois anos.

\subsubsection{Critérios para notificação ao SBDC}

Nem todos os atos de concentração são submetidos ao SBDC, porque a análise seria inviável e injustificada, uma vez que nem todos os atos de concentração são capazes de gerar algum efeito anticoncorrencial. Para isso, a Lei de Defesa da Concorrência estabelece alguns limites. Se $o$ ato de concentração atender a um ou a outro, deverá ser notificado ao SBDC.

O art. 54 da Lei 8.884/94 determina esses limites, a saber: (1) empresa ou grupo de empresas resultantes tenha participação de mercado relevante a partir de $20 \%$ ou (2) qualquer das empresas envolvidas na operação tenha tido faturamento superior a 400 milhões de reais (OCDE;BID, 2010). A relevância desses critérios é bastante discutida, e existe até um projeto de lei que visa alterá-los.

O regime no Brasil não exige notificação prévia dos atos de concentração. 0 processo de fusão ou aquisição envolvendo duas ou mais empresas já pode estar em andamento quando $o$ ato de concentração for notificado ao SBDC. Em virtude disso, a capacidade do Cade fica limitada em de fato reprovar um ato de concentração, por ter que determinar, em caso de reprovação, que as empresas desfaçam a operação, tarefa bastante onerosa e custosa para todos os envolvidos. 
Dessa forma, o Cade prefere adotar a postura de aprovar a operação, determinando algumas restrições e, assim, permitir que operações relevantes avancem. Como exemplo, quando da fusão Brahma e Antárctica para gerar a Companhia de Bebidas das Américas (Ambev), que acarretaria uma forte concentração de mercado no segmento de bebidas, o Cade determinou, entre outras medidas, a alienação de uma das marcas menores controladas pelas duas empresas, para assegurar a concorrência no mercado de bebidas (CAMARGOS; BARBOSA, 2005a).

\subsubsection{Números de atos de concentração}

Na Tabela 1, é possível observar um declínio do número de atos de concentração notificados em 2005 e 2006 em relação a 2004. Essa diminuição deveu-se à mudança do limite para notificação, que até 2004 referia-se ao piso de 400 milhões de reais do faturamento das requerentes no Brasil ou no mundo, sem restrição, e passou a referir-se ao faturamento de 400 milhões de reais somente de receitas brasileiras. Já o aumento do número de atos de concentração notificados em 2007 e 2008 é atribuído ao fortalecimento da economia e às flutuações da moeda, enquanto a queda em 2009 reflete a crise econômica mundial. Em 2010, o número de atos de concentração notificados voltou a aumentar, o que pode também ser atribuído ao crescimento da economia no Brasil e à busca das empresas em se fortalecer nesse ambiente altamente competitivo (OCDE; BID, 2010).

Tabela 1 - Atos de concentração de 2004 a 2010

\begin{tabular}{l|c|c|c|c|c|c|c}
\hline & 2004 & 2005 & 2006 & 2007 & 2008 & 2009 & 2010 \\
\hline $\begin{array}{l}\text { Atos de concentração } \\
\text { notificados }\end{array}$ & 516 & 386 & 411 & 591 & 616 & 457 & 483 \\
\hline Aprovados & 574 & 345 & 352 & 490 & 550 & 437 & 464 \\
\hline $\begin{array}{l}\text { Aprovados com } \\
\text { restrições }\end{array}$ & 43 & 37 & 20 & 37 & 58 & 19 & 18 \\
\hline \begin{tabular}{l} 
Reprovados \\
\hline
\end{tabular} & 1 & 0 & 0 & 0 & 1 & 1 & 1 \\
\hline
\end{tabular}

Fonte: Lei e Política de Concorrência no Brasil - Uma revisão pelos pares, 2010 (com adaptações) 
Segundo pesquisa realizada pela KPGM (2010), o número de F\&A registrou crescimento de $68 \%$ nos nove primeiros meses de 2010 , em relação ao mesmo período de 2009, e, caso esse ritmo seja mantido, as operações de F\&A ultrapassarão o recorde de 2008. Para isso, deve haver a manutenção do ritmo de aquisições de empresas lideradas por empresas estrangeiras no $4^{\circ}$ trimestre do ano. O Gráfico 1 permite a visualização dos setores que tiveram destaque em 2010:

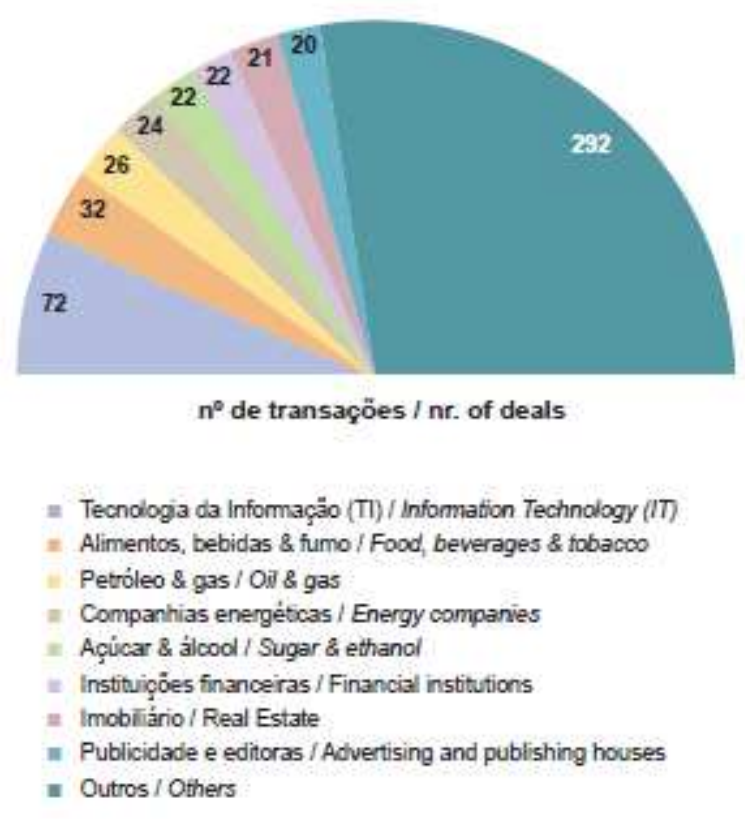

Gráfico 1 - Setores de Destaque em 2010

Fonte: KPMG, 2010, p. 4

\subsection{A Estratégia de Fusão e Aquisição}

Apesar de muitas vezes serem usados como sinônimos, os termos fusão, aquisição, incorporação recebem definições técnicas e legais distintas (GODOY; SANTOS, 2006). A Lei de Sociedades Anônimas (6.404/76), em seu artigo 227 conceitua aquisição como "operação em que uma ou mais sociedades são absorvidas por outra, que lhes sucede em todos os direitos e obrigações" e seu artigo 228 conceitua fusão como "operação pela qual se unem duas ou mais sociedades para formar sociedade nova, que Ihes sucederá em todos os seus direito e obrigações" (LEI $6.404,1976)$. 
Assim, a fusão caracteriza-se pelo desaparecimento das firmas anteriores à operação para constituir uma nova firma $(A+B=C)$, integrando as duas empresas em uma só, enquanto a aquisição é caracterizada pela manutenção da identidade da adquirente e extinção da identidade da adquirida $(A+B=A)$. (ORSI, 2006). Apesar dessa distinção legal, os termos são muitas vezes utilizados como sinônimos na prática, conforme mencionado. Para fins de simplificação, o mesmo acontecerá neste estudo, abrangendo F\&A como um processo de incorporação, independentemente de sua natureza legal ou contábil.

\subsubsection{Classificação das F\&A}

As F\&A podem ser classificadas de diversas formas tendo em vista um melhor entendimento dos impactos regulatórios e da geração de eficiências operacionais em cada categoria (OZMEL, 2006). Essa classificação pode ajudar no entendimento das sinergias e eficiências operacionais geradas pelo processo, bem como no esclarecimento de sua dinâmica.

Se o critério for nacionalidade das empresas envolvidas, uma F\&A pode ser classificada como doméstica ou cross-border, sob a óptica financeira, uma F\&A pode ser classificada como operacional ou estratégia e financeira; e, considerandose fatores econômicos e mercadológicos, uma F\&A pode ser horizontal, vertical ou em conglomerados (CAMARGOS; BARBOSA, 2004).

Sob a óptica da nacionalidade das empresas envolvidas, uma F\&A será doméstica quando envolver empresas de um mesmo país e cross border quando envolver uma ou mais empresas de diferentes países (CAMARGOS; BARBOSA, 2004). A estratégia cross border é muito utilizada pelas empresas quando visam à internacionalização, ou seja, entrar no mercado de um país que não o seu. Segundo Ansoff e McDonnell (2009), quando uma empresa se aventura no exterior, ela precisa buscar muito mais informações do que faz em seu ambiente doméstico, devido à presença de fatores econômicos, sociais, políticos e culturais estranhos à sua realidade. Muitas vezes a percepção de um estrangeiro é muito sutil quanto a esses fatores, ao passo que é muito aguçada para um nativo, razão pela qual 
diversas empresas buscam a estratégia de F\&A. As vantagens no uso de tal estratégia são eliminar alguns aspectos bastante onerosos para a adquirente, como compreensão da cultura e estudo do mercado local, instalação de planta, entre outros. Para Waack (2000), esse movimento de utilização de estratégia de F\&A visando à internacionalização pôde ser observado, sobretudo, nos anos 90 , apesar de ainda ser muito presente hoje em dia, conforme se vê no Gráfico 2, que mostra a proporção de F\&A cross border e doméstica na totalidade das F\&A do período (KPMG, 2010):

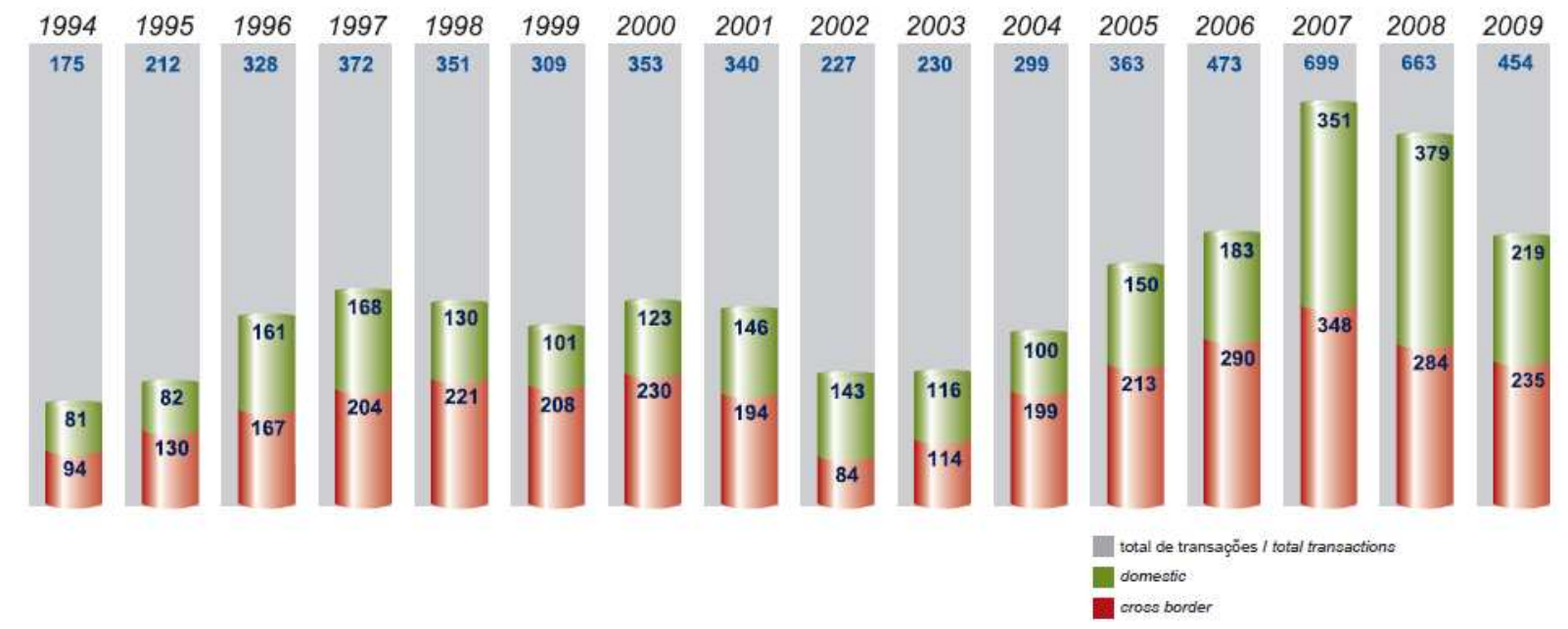

Gráfico 2 - Evolução anual do número de transações (1994 - 2009)

Fonte: KPMG, 2010, p. 20

Sob a óptica financeira, a F\&A pode ser classificada como estratégica, quando a operação for realizada visando à obtenção de sinergias, e financeira, quando nenhuma economia operacional significativa é esperada (CAMARGOS; BARBOSA, 2004). Consoante essa definição, Oliveira e Rocha (2006) definem como fusão estratégica aquela que visa atingir eficiências operacionais, como economia de escala, eliminação de funções redundantes, aumento da participação de mercado, economia de escopo, e fusões financeiras como sendo aquelas que envolvem empresas que podem ser reestruturadas para melhora do fluxo de caixa por meio de cortes de custos e vendas de ativos improdutivos. O foco do presente estudo recairá sobre as fusões estratégicas, uma vez que, segundo definição, elas são realizadas quando as empresas envolvidas buscam atingir eficiências operacionais.

Por fim, considerando-se fatores econômicos e mercadológicos, uma F\&A pode ser classificada como sendo horizontal, caracterizada pela união entre empresas que 
atuam na mesma linha de negócio; vertical, caracterizada pela união entre empresas que atuam no mesmo processo produtivo; ou em conglomerados, caracterizada pela combinação de empresas em negócios não relacionados (SUEN; KIMURA, 1997).

As F\&A horizontais resultam em aumento do poder de mercado, o que ocasiona aumento do nível de preços, uma vez que diminuem o número de atores no mercado. Geralmente esse tipo de fusão ocorre entre concorrentes que visam ao fortalecimento da sua posição no mercado frente aos demais concorrentes, além da busca por eficiências operacionais.

OZMEL (2006) afirma, pois, que as concentrações horizontais reduzem o número de concorrentes independentes da indústria, o que diminui os custos de monitoramento entre cada empresa e incentiva as empresas a se envolverem em um comportamento de conluio e, consequentemente, aumenta os preços e diminui a produção. Dessa forma, as fusões horizontais podem gerar efeitos anticompetitivos devido ao aumento da concentração de mercado, e por isso devem ser analisadas com bastante cautela pelo SBCD (KLOECKENER, 1994). Alguns exemplos de fusão horizontal que ocorreram no Brasil são: Brahma e Antárctica, originando a Ambev; Banco Real e Banco Santander; Banco do Brasil e Nossa Caixa; Perdigão e Sadia; TAM e LAN.

As F\&A verticais resultam na união de firmas que participam do mesmo processo produtivo, podendo ser em direção ao fornecedor (montante) ou em direção aos distribuidores (jusante), e visam, sobretudo, à eliminação de custos de transação e eficiências operacionais por meio da integração da operação (CAMARGOS; BARBOSA, 2004). Como exemplo tem-se a fusão vertical entre a Parmalat e a Mococa.

Por fim, as fusões em conglomerados ocorrem entre empresas que não possuem negócios relacionados, mas objetivam diversificação do risco e aproveitamento de oportunidades de investimento (OLIVEIRA; FORTE; RAGÃO, 2007). As fusões em conglomerados podem ser divididas em três tipos característicos:

a) extensão do produto: ocorre entre empresas que possuem certa relação entre si e buscam o aumento da linha de produtos; 
b) extensão geográfica de mercados: ocorre entre empresas que atuam em mercados distintos, como mercado doméstico x mercado externo;

c) conglomerado puro: ocorre entre empresas cujos negócios não são, de forma alguma, relacionados.

Um exemplo de fusão em conglomerados ocorreu entre a RJR (empresa de tabaco) com a Nabisco (empresa de alimentos).

Em resumo, as classificações dos processos de F\&A podem ser visualizadas no Quadro 1:

\begin{tabular}{|c|c|c|c|}
\hline Classificação & Tipo & Definição & Objetivo \\
\hline \multirow[t]{2}{*}{ Nacionalidade } & Doméstica & $\begin{array}{l}\text { Envolve empresas do } \\
\text { mesmo país }\end{array}$ & $\begin{array}{l}\text { - Aumento do market share; } \\
\text { - Proteção contra } \\
\text { aquisições indesejadas; } \\
\text { - Fortalecimento da posição } \\
\text { no mercado. }\end{array}$ \\
\hline & Cross border & $\begin{array}{c}\text { Envolve empresas de } \\
\text { países distintos }\end{array}$ & $\begin{array}{l}\text { - Internacionalização (em } \\
\text { geral) }\end{array}$ \\
\hline \multirow[t]{2}{*}{$\begin{array}{c}\text { Óptica } \\
\text { financeira }\end{array}$} & Estratégica & $\begin{array}{c}\text { Operação visa à } \\
\text { obtenção de sinergias }\end{array}$ & $\begin{array}{l}\text { - Economia de escala; } \\
\text { - Economia de escopo; } \\
\text { - Transferência de } \\
\text { tecnologia; } \\
\text { - Aumento do market share }\end{array}$ \\
\hline & Financeira & $\begin{array}{l}\text { Operação não visa à } \\
\text { obtenção de sinergias }\end{array}$ & $\begin{array}{l}\text { - Melhora do fluxo de caixa; } \\
\text { - Corte de custos. }\end{array}$ \\
\hline $\begin{array}{c}\text { Fatores } \\
\text { econômicos e } \\
\text { mercadológicos }\end{array}$ & Horizontal & $\begin{array}{l}\text { Operação envolvendo } \\
\text { empresas de um } \\
\text { mesmo setor, } \\
\text { geralmente } \\
\text { concorrentes }\end{array}$ & $\begin{array}{l}\text { - Aumento do market share; } \\
\text { - Economias de escala e de } \\
\text { escopo; } \\
\text { - Aumento do poder de } \\
\text { mercado }\end{array}$ \\
\hline
\end{tabular}




\begin{tabular}{|c|c|c|c|}
\hline & Vertical & $\begin{array}{c}\text { Operação envolvendo } \\
\text { empresas } \\
\text { pertencentes a um } \\
\text { mesmo processo } \\
\text { produtivo }\end{array}$ & $\begin{array}{l}\text { - Eliminação de custos de } \\
\text { transação; } \\
\text { - Integração. }\end{array}$ \\
\hline & Conglomerado & $\begin{array}{l}\text { Operação envolvendo } \\
\text { empresas não } \\
\text { relacionadas }\end{array}$ & $\begin{array}{l}\text { - Diversificação do risco; } \\
\text { - Aproveitamento de } \\
\text { oportunidades de } \\
\text { investimento }\end{array}$ \\
\hline
\end{tabular}

Quadro 1 - Tipos e motivos da ocorrência de F\&A

Fonte: Elaboração própria a partir de Oliveira, Forte e Ragão (2007)

Conclusão

\subsubsection{Causas e motivos das F\&A}

As fusões e aquisições ocorrem por razões diversas, dependendo dos objetivos e estratégias das empresas envolvidas. Dessa forma, a presente seção visa elencar quais são as motivações para os processos de F\&A e assim permitir embasamento mais sólido para analisar as eficiências operacionais geradas por tais processos.

As razões dos processos de F\&A variam desde a entrada em novos mercados e acesso a fornecedores e clientes até uma melhor gestão e força de trabalho adicional (HARANSKY, 1999).

De maneira genérica, os processos de F\&A são uma maneira rápida de a empresa crescer por meio da associação com outra, fato que ganhou destaque no cenário atual devido à crescente internacionalização de empresas (CAMARGOS; BARBOSA, 2005a).

O uso da estratégia de F\&A visando à internacionalização foi recorrente nas últimas décadas, sobretudo nos anos 90, e contrasta com as décadas anteriores, quando a estratégia era a construção de novas filiais e plantas, em que as empresas buscavam crescer internamente, sem recorrer a outras estratégias (MIRANDA; MARTINS, 2000). Entretanto, a nova onda de F\&A é motivada muito mais por questões estratégicas e para criar barreiras à entrada de novos concorrentes, o que 
aumenta o poder de mercado das empresas envolvidas na operação, do que por ganhos financeiros rápidos (PATROCíNIO et al., 2005).

Rápido crescimento e internacionalização não são as únicas motivações para as empresas buscarem a estratégia de F\&A, que, apesar de efetiva em muitos casos, envolve inúmeros riscos. Segundo Camargos e Barbosa (2005a):

\begin{abstract}
Os processos de fusão e aquisição que ocorrem atualmente visam basicamente 0 acesso a novos mercados, tecnologias e competências, maior poder econômico e de competição, sinergias e melhoria de eficiências administrativas e operacionais, diminuição do risco operacional e financeiro, proteção de mercado contra a entrada de concorrentes estrangeiros, aquisições indesejadas ou a simples sobrevivência (CAMARGOS; BARBOSA, 2005a, p. 48).
\end{abstract}

$\mathrm{Na}$ extensa literatura sobre F\&A, algumas hipóteses foram propostas para explicar suas motivações (WESTON apud CAMARGOS; BARBOSA, 2009; BETHLEM, 2005):

a) hipótese monopolística: F\&A motivada pela eliminação de competidores;

b) hipótese da promoção de papéis: F\&A motivada pela venda ao público de papéis com os preços inflacionados;

c) hipótese da eficiência: F\&A motivada pela busca de eficiências operacionais e sinergias, como redução dos custos, expansão das vendas, otimização da produção, etc.;

d) hipótese da informação: F\&A motivada pelo efeito de curto prazo no valor de mercado das ações, o qual os investidores tentam incorporar;

e) hipótese da agência: F\&A motivada para minimizar os custos e problemas de agência; ${ }^{1}$

f) hipótese dos impostos: F\&A motivada por ganhos tributários;

\footnotetext{
${ }^{1}$ Custo de agência: custos em que os acionistas incorrem para alinhar os interesses dos tomadores de decisão (gestores) aos seus.
} 
Quanto à hipótese dos impostos, é importante destacar que a adquirente pode ser motivada a realizar uma operação de F\&A para absorver os prejuízos da adquirida em suas demonstrações financeiras, e assim auferir ganhos tributários decorrentes desse processo. Além disso, de acordo com a hipótese dos impostos, os ganhos fiscais podem ser decorrentes de um melhor planejamento tributário (KEY apud PASIN; MATIAS, 2001; KLOECKENER, 1994).

De maneira sintética, os vários motivos para ocorrer F\&A podem ser agrupados em três grandes contextos: crescimento e diversificação; sinergia; e aumento de capacidades. Motivadas por crescimento e diversificação, as empresas que utilizam o processo de F\&A conseguem rápido acesso a novos mercados, transpondo barreiras mercadológicas e até mesmo culturais. Aquelas que visam à obtenção de sinergias são motivadas pelas economias de escala e de escopo resultantes da operação e, por fim, as que visam ao aumento de capacidades e são motivadas pelo crescimento de sua capacidade administrativa, financeira, tecnológica. (SUEN; KIMURA, 1997).

Além dessas razões, a exploração de ativos de outras empresas, como a associação à marca (OZMEL, 2006) e a busca pelo acesso a conhecimento e tecnologia (BRESMAN et al., 1999), são motivações importantes para a ocorrência de F\&A.

As motivações de F\&A pela associação à marca e acesso a conhecimento e tecnologia são importantes fontes de vantagem competitiva, uma vez que, segundo Ribeiro e Oliveira Júnior (2009), parafraseando Bancy (1991)

Os recursos intangíveis normalmente criam vantagens competitivas mais sustentáveis do que os recursos tangíveis, porque os concorrentes têm mais dificuldade de entendê-los e imitá-Ios (RIBEIRO; OLIVEIRA JÚNIOR, 2009, p. 83).

Como é possível observar, as razões para ocorrência dos processos de F\&A são as mais diversas, entretanto podem ser divididas entre aquelas que maximizam a riqueza dos acionistas e as que maximizam a utilidade gerencial.

Problema de agência: gestores tomam decisão visando maximizar sua utilidade pessoal, e não a riqueza dos acionistas, motivo pelo qual são contratados (IBGC). 
A maximização da riqueza dos acionistas ocorre porque o anúncio ou a simples expectativa da ocorrência de um processo de F\&A gera retornos anormais positivos. Estudos comprovam, todavia, que as F\&A geram ganhos positivos para os acionistas da empresa adquirida, com resultados não significativos ou mesmo negativos para os acionistas das adquirentes (KAYO et al., 2009; CAMARGOS; BARBOSA, 2007; BRITO et al., 2005). Contudo, independentemente do real motivo, o simples anúncio de um processo de F\&A impacta o valor das ações no mercado, pois os investidores tentarão otimizar os ganhos ou minimizar as perdas ocasionadas pela operação (CAMARGOS; ROMERO, 2006).

A maximização da utilidade gerencial, por sua vez, ocorre quando a F\&A visa tanto ao aumento do bem-estar dos diretores das firmas quanto à substituição da administração ineficiente de uma empresa. (CAMARGOS; BARBOSA, 2003). Segundo Camargos e Barbosa (2003), três teorias dão suporte a essas razões:

\footnotetext{
Teoria do Mercado Corporativo (F\&A tem por objetivo substituição de administradores ineficientes); Teoria do Fluxo de Caixa Livre (F\&As são maneiras de administradores gastarem dinheiro ao invés de distribuí-los aos acionistas); Teoria da Maximização do Crescimento (os administradores maximizam o crescimento de suas firmas, mais do que os lucros ou o bem-estar dos acionistas) (CAMARGOS; BARBOSA, 2003, p. 25).
}

A Teoria da Agência, uma das principais de finanças e considerada a principal abordagem para a governança corporativa, estipula que os interesses e direitos dos acionistas e gestores devem ser alinhados, ou seja, ambas as partes agem tendo em vista a maximização de suas utilidades pessoais.

De acordo com o Instituto Brasileiro de Governança Corporativa (IBGC), a busca pela maximização da utilidade gerencial acarreta o problema da agência, pois os gestores tomam decisões com o intuito de maximizar sua utilidade pessoal e não a riqueza dos acionistas, razão pela qual eles foram contratados. A maximização da utilidade gerencial, portanto, vai de encontro à Teoria da Agência.

As motivações para ocorrência de F\&A variam também sob as ópticas da empresa adquirida e da adquirente. Geralmente, os executivos das empresas adquirentes consideram mais relevantes questões de mercado ao comprarem outras organizações, enquanto as empresas adquiridas são em geral vendidas por questões financeiras ou de transação (TANURE; CANÇADO, 2005). 
Da óptica das adquirentes, quando se fala da relevância dada a questões de mercado, muitas vezes elas buscam o fortalecimento de sua posição e aumento de seu poder de mercado. Nos Estados Unidos, 44\% das F\&A ocorridas entre 19911992 foram motivadas por aumento do poder de mercado, enquanto entre 19851986 esse percentual correspondia a apenas 11\% (OZMEL, 2006). Percebe-se, portanto, que a busca pelo aumento do poder de mercado tem crescido, e ele se justifica pelo aumento da concorrência, em que as empresas muitas vezes têm que se associar para conseguir sobreviver no mercado.

As motivações para a ocorrência de F\&A variam ainda de acordo com a classificação da operação, ou seja, se é fusão horizontal, vertical ou por conglomerados. As fusões verticais e sobretudo as horizontais são motivadas principalmente pela geração de eficiências operacionais, enquanto as fusões em conglomerados derivam de inúmeras razões que não a geração de eficiências operacionais, como a diversificação do risco (DEVOS; KADAPAKKAM; KRISHNAMURTHY, 2009).

\subsubsection{Sinergias e eficiências operacionais}

O tema de fusões e aquisições é um dos mais controversos na administração e as teorias ainda não conseguiram decifrá-lo por inteiro, restando muitas lacunas que necessitam ser preenchidas. As pesquisas sobre o tema de F\&A ainda são muito generalistas e contraditórias, e isso se deve, em grande parte, ao caráter secreto dessas operações, o que impede seu completo entendimento (ROSS et al., 1995). Em virtude disso também, não há consenso quanto à real geração de eficiências operacionais decorrentes dos processos de F\&A. Nesse contexto, esta seção visa elencar quais seriam essas eficiências operacionais para analisar, nos próximos capítulos, se elas ocorrem ou não.

Primeiramente, para que o entendimento seja mais claro, é importante nivelar o conceito de sinergia, tema central desta seção. Cabe destacar ainda que no presente estudo os termos sinergia e eficiências operacionais serão utilizados como sinônimos. 
Segundo Ross et al. (1995), sinergia é a diferença de valor de mercado entre a empresa combinada e a soma dos valores de cada empresa antes da junção. A sinergia ocorre quando as empresas consolidadas conseguem operar mais eficientemente do que o faziam antes, separadamente. Consoante essa orientação, Weston e Brigham (2000) definem:

[...] sinergia como a condição pela qual o todo é maior do que a soma das partes; em uma fusão sinérgica, o valor pós-fusão supera a soma dos valores pré-fusão das empresas separadas (WESTON; BRIGHAM apud CAMARGOS; BARBOSA, 2005b, p. 101).

Ainda que no planejamento da operação estime-se a geração de eficiências operacionais, ou seja, de sinergias, é essencial que os ganhos sejam mensurados, pois podem nem ocorrer em reorganizações corporativas malfeitas (PASIN; MATIAS, 2001). Assim, a estratégia elaborada para a operação de $F \& A$ não termina quando se conclui a operação. Muito pelo contrário: a transição da operação, em que as empresas estão de fato se unindo, é a etapa mais crítica do processo e, se não for bem gerenciada, poderá ocasionar custos em detrimento dos ganhos inicialmente estimados. Quanto mais rápida for a integração, mais rápido surgirão as sinergias (KEY apud PASIN; MATIAS, 2001).

Além da geração de sinergias ser afetada pela efetividade da transação e pela velocidade em que ela ocorre, depende da maneira como a operação é conduzida pela adquirida, se de forma hostil ou amigável. Camargos e Barbosa (2006) fazem a seguinte definição desses conceitos:

A amigável pode ser definida como uma mudança na propriedade corporativa, sem uma mudança no controle administrativo, enquanto a hostil pode ser definida como um lance de tomada de controle não-solicitado que resulta na substituição da administração da firma-alvo (CAMARGOS; BARBOSA, 2006, p. 48).

Fusões hostis se caracterizam geralmente como de natureza disciplinar, e as amigáveis como sinérgicas. Em virtude disso, não se espera geração de eficiências operacionais nas fusões conduzidas de maneira hostil. Assim, como sinergia (fusão amigável) em detrimento de disciplina gerencial (fusão hostil) constitui o motivo central para a ocorrência de F\&A, as empresas adquirentes preferem comprar plantas produtivas e melhorar sua produtividade após a fusão. (DEVOS; KADAPAKKAM; KRISHNAMURTHY, 2009). 
Conforme indicado, a geração de eficiências é o penúltimo ponto analisado pelo SBDC. Para a análise chegar a esse nível, as empresas envolvidas na operação provavelmente exercerão poder de mercado, e, para ter a operação aprovada, deverão provar que são capazes de gerar eficiências operacionais que não podem ser geradas de outra forma em um período inferior a dois anos.

O SBDC parte do princípio que as eficiências geradas serão divididas entre todos os envolvidos no mercado e repassadas ao consumidor na forma de preços mais baixos, maior variedade de produtos ofertados, maior qualidade, mais inovação (NGUYEN; OLLINGER, 2006). Entretanto, os incrementos de eficiência são difíceis de verificar e quantificar, em parte porque as informações necessárias se referem a eventos futuros (Portaria SEAE/SDE no 50, 2001, SAMUELS et al., 1990).

Em se tratando especificamente das sinergias geradas pelo processo de $F \& A$, as principais são aumento de receita, diminuição de custos, diminuição de impostos, diminuição de custo de capital (ROSS et al., 1995). Além dessas, é possível obter (LEMES JR; RIGO; CHEROBIM apud CAMARGOS; BARBOSA, 2005b; Portaria SEAE/SDE no 50, 2001):

a) economias de escala: reduções nos custos médios derivadas da expansão da quantidade produzida, dados os preços dos insumos. Ocorrem quando os custos fixos representam parcela significativa dos custos totais e a produtividade do trabalho ou do capital aumenta;

b) economias financeiras: advindas de melhor estrutura de capital e maior capacidade para alavancagem;

c) economias de escopo: reduções nos custos médios derivadas da produção conjunta de bens distintos. Como exemplo disso, tem-se a utilização de maquinário ocioso, aproveitamento de matéria-prima, de capacidade produtiva ociosa e de mão de obra, entre outros;

d) eficiência gerencial: advindas da substituição da administração ineficiente, com consequente melhora do desempenho econômico e financeiro das empresas;

e) maior poder de mercado: maior poder de negociação, de competição; 
f) economias fiscais: utilização de isenções e compensações autorizadas por lei, como eliminação da bitributação, planejamento tributário e incorporação de prejuízos operacionais;

g) introdução de uma nova tecnologia: tornar viável o lançamento de um produto, a introdução de tecnologias que incrementem o nível de produtividade.

Todavia, O Guia para Análise Econômica de Atos de Concentração Horizontal (Portaria SEAE/SDE no 50, 2001) considera somente as eficiências de escala, escopo e introdução de nova tecnologia. Dessa forma, as empresas que submetem atos de concentração ao SBDC devem ser capazes de provar que a operação é capaz de gerar alguma dessas três sinergias.

Brealey e Myers (apud CAMARGOS; BARBOSA, 2004) acreditam que as sinergias nos processos de $F \& A$ podem ser obtidas de três maneiras:

a) sinergia por transferência: transferência de tecnologia, conhecimento, competências;

b) sinergia por partilha: partilha de recursos, de know-how;

c) sinergia por conluio: aumento da vantagem competitiva e poder de monopólio.

Os próximos capítulos vão tratar dos métodos e técnicas de pesquisa utilizados neste estudo para verificar se os processos de F\&A geram ou não eficiências operacionais para as empresas envolvidas e também a apresentação e análise dos resultados obtidos. 


\section{MÉTODOS E TÉCNICAS DE PESQUISA}

Neste capítulo, apresenta-se a forma como a pesquisa foi realizada, classificando-a com base em seus objetivos. Além disso, são definidas a população e a amostra do estudo, apresentado os instrumentos tanto de pesquisa como de análise e coleta dos dados.

\subsection{Tipo e descrição geral da pesquisa}

Existem várias formas de classificar as pesquisas, cada uma obedecendo a algum critério. Segundo Silva e Menezes (2001), são quatro as classificações possíveis, dependendo do ponto de vista adotado: objetivos, natureza, forma de abordagem do problema e procedimentos técnicos.

A presente pesquisa, que tem como objetivo geral analisar as eficiências operacionais decorrentes dos processos de F\&A de empresas, enquadra-se como pesquisa descritiva. Segundo Gil (2002), geralmente os pesquisadores sociais preocupados com a atuação prática utilizam-se desse tipo de pesquisa, que

[...] têm como objetivo primordial a descrição das características de determinada população ou fenômeno ou, então, o estabelecimento de relações entre variáveis (GIL, 2002, p. 46).

Adotando o critério de natureza, a presente pesquisa classifica-se como aplicada, por ter o objetivo de gerar conhecimento para a aplicação prática da análise do problema de pesquisa (SILVA; MENEZES, 2001). Em geral, os projetos de pesquisa das Ciências Sociais Aplicadas, na qual a Administração se enquadra, classificamse como aplicadas.

Quanto à forma de abordagem do problema, classifica-se como quantitativa, e realiza a análise da média do desempenho dos indicadores financeiros, sua variação, bem como a análise de cluster. 
Por fim, quanto aos procedimentos técnicos utilizados, o presente estudo classificase como pesquisa documental utilizando-se, consequentemente, de dados secundários. Segundo Gil (2002) e Lakatos e Marconi (2001), a pesquisa documental se vale de fontes que não receberam tratamento analítico, ou que podem ser analisadas sob nova óptica, tendo como base os objetivos da pesquisa. Não se trata, pois, de mera repetição do que há na literatura sobre determinado assunto, mas sim de abordagem do tema sob novo enfoque. As vantagens de utilizar a pesquisa documental residem no fato de os documentos constituírem fonte rica e estável de dados, de apresentar reduzidos custos e também de não exigir contato com os sujeitos de pesquisa. Logicamente, esse tipo de pesquisa também apresenta suas limitações, e as críticas mais frequentes referem-se à não representatividade e à subjetividade dos documentos.

\subsection{População e amostra}

Para operacionalizar o presente estudo, optou-se pela adoção de análise censitária que totalizou 4.178 atos de concentração notificados ao Cade entre os anos de 2000 a 2010, cada um envolvendo no mínimo duas empresas.

Para o levantamento dos atos de concentração, utilizou-se o sistema interno da SEAE, em que os dados puderam ser obtidos de maneira mais sistemática, mas percebeu-se uma limitação: como o sistema interno da SEAE só passou a ser utilizado efetivamente a partir de 2002, poderia acontecer de algum ato de concentração notificado entre 2000 e 2002 não estar registrado no sistema, o que ocasionaria uma perda para a pesquisa. Por isso, optou-se por restringir o censo entre os anos de 2002 a 2010, totalizando 4.174 atos de concentração.

Cabe frisar que a pesquisa no sistema interno da SEAE objetivou apenas levantar o número do processo dos atos de concentração notificados entre 2002 e 2010 . As demais informações foram coletadas no sítio da SEAE, de domínio público, o que implica dizer que não foi utilizado nenhum dado confidencial das empresas.

Dando continuidade à etapa de composição da amostra, procedeu-se à segunda restrição baseada em um dos objetivos específicos definido, que visa identificar as motivações das empresas para a adoção da estratégia de F\&A. Restringiu-se, 
assim, a amostra somente àqueles atos de concentração em que houve análise de eficiência, no total de 61 .

Outra restrição na amostra da pesquisa decorreu da proposta do estudo, de analisar indicadores financeiros para identificar a geração ou não de eficiências operacionais. Com isso, limitou-se a amostra somente àqueles atos de concentração em que pelo menos uma das empresas envolvidas possuísse capital aberto. Com a consequente diminuição do número de atos de concentração, iniciou-se a análise por empresa e não mais por ato de concentração, o que a tornou mais específica e envolveu o total de 134 empresas.

Tendo em vista ainda a análise dos indicadores financeiros que seria feita, para comparar o desempenho das empresas em cada indicador no ano da reestruturação e nos dois anos seguintes, foram excluídas da amostra empresas cujos atos de concentração foram notificados em 2008, 2009 e 2010, pois não seria possível obter deles os dados financeiros necessários para a análise. Retiraram-se da amostra também empresas que, embora de capital aberto, estavam com seus dados financeiros indisponíveis. Após esses dois últimos filtros, a amostra final utilizada no presente estudo alcançou 35 empresas.

Assim, foi este o critério adotado para a composição da amostra da pesquisa e coleta dos dados: atos de concentração notificados entre 2002 e 2008, em que houve análise de eficiência envolvendo empresas de capital aberto.

O Quadro 2 compila os atos de concentração da amostra analisada com 0 respectivo ano de notificação, setor de atuação das requerentes e tipo de operação (fusão, aquisição, joint venture, etc). As 35 empresas que compuseram a amostra da pesquisa estão destacadas em negrito. 


\begin{tabular}{|c|c|c|c|c|c|c|c|c|}
\hline & \multicolumn{2}{|c|}{ Requerente 1} & \multicolumn{2}{|c|}{ Requerente 2} & \multicolumn{2}{|c|}{ Requerente 3} & \multirow{2}{*}{$\begin{array}{c}\text { Ano da } \\
\text { Combinação }\end{array}$} & \multirow{2}{*}{ Tipo } \\
\hline & Empresa & Setor & Empresa & Setor & Empresa & Setor & & \\
\hline 01 & $\begin{array}{l}\text { Cia Brasileira de } \\
\text { Distribuiçãao } \\
\text { [Adquirente] }\end{array}$ & Varejo & $\begin{array}{l}\text { Hermes } \\
\text { (Grupo) } \\
\text { [Adquirida] }\end{array}$ & Varejo & $\begin{array}{c}\text { Jerônimo Martins SGPS } \\
\text { S.A. } \\
\text { (Grupo) } \\
\text { [Adquirida] }\end{array}$ & Varejo & 2002 & Aquisição \\
\hline 02 & $\begin{array}{l}\text { Br Participações e } \\
\text { Empreendimentos } \\
\text { (Grupo) } \\
\text { [Adquirente] }\end{array}$ & Varejo & $\begin{array}{l}\text { Supermercados Lusita } \\
\text { [Adquirida] }\end{array}$ & Varejo & - & - & 2002 & Aquisição \\
\hline 03 & $\begin{array}{c}\text { Cia Ultragaz S.A. } \\
\text { (Grupo) } \\
\text { [Adquirente] }\end{array}$ & $\begin{array}{l}\text { Químico } \\
\text { Petroquímico }\end{array}$ & $\begin{array}{c}\text { Shell Gás (LPG) Brasil S.A. } \\
\text { (Grupo) } \\
\text { [Adquirida] }\end{array}$ & Petroquímico & - & - & 2003 & Aquisição \\
\hline 04 & $\begin{array}{l}\text { Suzano Bahia Sul Papel } \\
\text { e Celulose } \\
\text { [Adquirente] }\end{array}$ & $\begin{array}{l}\text { Papel e celulose } \\
\text { Químico } \\
\text { Petroquímico }\end{array}$ & $\begin{array}{c}\text { Ripasa Celulose e Papel } \\
\text { [Adquirida] }\end{array}$ & Papel e celulose & - & - & 2004 & Aquisição \\
\hline 05 & $\begin{array}{c}\text { Braco S.A. Cia de } \\
\text { Bebidas da Américas - } \\
\text { AMBEV } \\
\text { [Adquirida] }\end{array}$ & Bebida & $\begin{array}{c}\text { Interbrew N.V. S/A } \\
\text { [Adquirente] }\end{array}$ & Bebida & - & - & 2004 & Aquisição \\
\hline 06 & $\begin{array}{l}\text { United Technologies } \\
\text { Corporation } \\
\text { [Adquirente] }\end{array}$ & $\begin{array}{c}\text { Indústria mecânica e mecânica leve } \\
\text { Eletrônica } \\
\text { Informática } \\
\text { Telecomunicações }\end{array}$ & $\begin{array}{l}\text { Linde Ag. } \\
\text { [Adquirida] }\end{array}$ & $\begin{array}{c}\text { Indústria mecânica leve } \\
\text { Químico } \\
\text { Petroquímico } \\
\text { Automobilístico } \\
\text { Transporte } \\
\end{array}$ & & & 2004 & Aquisição \\
\hline 07 & $\begin{array}{c}\text { Petrobras Distribuidora } \\
\text { S/A } \\
\text { (Grupo) } \\
\text { [Adquirente] }\end{array}$ & Petroquímico & $\begin{array}{l}\text { Agip do Brasil Ltda } \\
\text { [Adquirida] }\end{array}$ & Petroquímico & - & - & 2004 & Aquisição \\
\hline 09 & $\begin{array}{l}\text { Carrefour Brasil } \\
\text { Comércio e Indústria } \\
\text { Ltda } \\
\text { (Grupo) }\end{array}$ & Varejo & $\begin{array}{l}\text { Sonae Distribuição Brasil } \\
\text { S.A }\end{array}$ & Varejo & - & - & 2005 & Aquisição \\
\hline 10 & $\begin{array}{l}\text { Americanas.com } \\
\text { (Grupo) } \\
\text { [Adquirente] }\end{array}$ & Varejo & $\begin{array}{l}\text { Shoptime S.A. } \\
\text { [Adquirida] }\end{array}$ & Empresa de participações & $\begin{array}{c}\text { TV Sky Shop S.A. } \\
\text { (Grupo) } \\
\text { [Adquirida] }\end{array}$ & Varejo & 2005 & Aquisição \\
\hline 11 & $\begin{array}{l}\text { International Paper } \\
\text { Investments } \\
\text { (Grupo) }\end{array}$ & $\begin{array}{c}\text { Papel } \\
\text { Embalagem } \\
\text { Reflorestamento }\end{array}$ & $\begin{array}{l}\text { International Paper do } \\
\text { Brasil Ltda. } \\
\text { (Grupo) }\end{array}$ & $\begin{array}{c}\text { Papel } \\
\text { Embalagem } \\
\text { Reflorestamento }\end{array}$ & $\begin{array}{l}\text { Vorotantim Celulose e } \\
\text { Papel S.A. }\end{array}$ & $\begin{array}{l}\text { Papel e celulose } \\
\text { Produtos } \\
\text { minerais não } \\
\text { metálicos } \\
\text { Químico }\end{array}$ & 2006 & $\begin{array}{l}\text { Permuta de } \\
\text { ativos }\end{array}$ \\
\hline 12 & $\begin{array}{l}\text { Dana Corporation } \\
\text { [Adquirida] }\end{array}$ & $\begin{array}{l}\text { Indústria automobilística e de } \\
\text { transporte }\end{array}$ & $\begin{array}{l}\text { Mahle GMBH. } \\
\text { (Grupo) } \\
\text { [Adquirente] }\end{array}$ & $\begin{array}{l}\text { Indústria automobilística e de } \\
\text { transporte }\end{array}$ & - & (2) -im & 2006 & Aquisição \\
\hline 13 & $\begin{array}{l}\text { Americanas.com } \\
\text { (Grupo) }\end{array}$ & Varejo & Submarino S.A. & Varejo & - & - & 2006 & Fusão \\
\hline
\end{tabular}




\begin{tabular}{|c|c|c|c|c|c|c|c|c|}
\hline & \multicolumn{2}{|c|}{ Requerente 1} & \multicolumn{2}{|c|}{ Requerente 2} & \multicolumn{2}{|c|}{ Requerente 3} & \multirow{2}{*}{$\begin{array}{c}\text { Ano da } \\
\text { combinação }\end{array}$} & \multirow{2}{*}{ Tipo } \\
\hline & Empresa & Setor & Empresa & Setor & Empresa & Setor & & \\
\hline 14 & $\begin{array}{c}\text { Akzo Nobel N.v. } \\
\text { (Grupo) } \\
\text { [Adquirida] }\end{array}$ & $\begin{array}{l}\text { Farmacêutico } \\
\text { Petroquímico } \\
\text { Químico }\end{array}$ & $\begin{array}{l}\text { Schering-Plough } \\
\text { Corporation } \\
\text { [Adquirente] }\end{array}$ & $\begin{array}{l}\text { Farmacêutico } \\
\text { Produtos de higiene } \\
\text { Cosméticos } \\
\text { Perfumaria }\end{array}$ & - & - & 2007 & Aquisição \\
\hline 15 & $\begin{array}{c}\text { Petróleo Brasileiro S.A. } \\
\text { [Adquirente] }\end{array}$ & Petroquímico & $\begin{array}{l}\text { Refinaria de Petróleo } \\
\text { Ipiranga S.A. } \\
\text { (Grupo) } \\
\text { [Adquirida] }\end{array}$ & $\begin{array}{l}\text { Químico } \\
\text { Petroquímico }\end{array}$ & - & - & 2007 & Aquisição \\
\hline 16 & $\begin{array}{c}\begin{array}{c}\text { Hypermarcas } \\
\text { [Adquirente] }\end{array} \\
\end{array}$ & $\begin{array}{c}\text { Alimentos } \\
\text { Farmacêutico } \\
\text { Produtos de higiene }\end{array}$ & $\begin{array}{l}\text { DM Indústria Farmacêutica } \\
\text { Ltda. } \\
\text { [Adquirida] }\end{array}$ & $\begin{array}{l}\text { Farmacêutico } \\
\text { Cosméticos } \\
\text { Alimentos } \\
\end{array}$ & - & - & 2007 & Aquisição \\
\hline 17 & $\begin{array}{c}\text { Braskem } \\
\text { [Adquirente] }\end{array}$ & Petroquímico & $\begin{array}{c}\text { Petróleo Brasileiro S.A. } \\
\text { [Adquirente] }\end{array}$ & Petroquímico & - & - & 2007 & Aquisição \\
\hline 18 & $\begin{array}{l}\text { Dow Brasil S.A. } \\
\text { (Grupo) }\end{array}$ & $\begin{array}{c}\text { Higiene pessoal } \\
\text { Químico } \\
\text { Petroquímico } \\
\text { Produtos veterinários e para } \\
\text { agricultura } \\
\end{array}$ & $\begin{array}{l}\text { Chevron Phillips Chemical } \\
\text { Company LLC }\end{array}$ & $\begin{array}{l}\text { Químico } \\
\text { Petroquímico }\end{array}$ & - & - & 2007 & Joint-venture \\
\hline 19 & $\begin{array}{c}\text { GTI S.A. } \\
\text { (Grupo) } \\
\text { [Adquirente] }\end{array}$ & Transporte aéreo & $\begin{array}{l}\text { VRG Linhas Aéreas S.A. } \\
\text { [Adquirida] }\end{array}$ & Transporte aéreo & - & - & 2007 & Aquisição \\
\hline 20 & $\begin{array}{l}\text { Cia de Bebidas das } \\
\text { Américas } \\
\text { [Adquirente] }\end{array}$ & Bebida & $\begin{array}{l}\text { José de Sousa Cintra } \\
\text { [Adquirida] }\end{array}$ & Bebida & - & - & 2007 & Aquisição \\
\hline 21 & $\begin{array}{l}\text { Google Inc. } \\
\text { [Adquirente] }\end{array}$ & Internet & $\begin{array}{c}\text { Click Holding Corp. } \\
\text { [Adquirida] }\end{array}$ & Publicidade online & - & - & 2007 & Aquisição \\
\hline 23 & $\begin{array}{l}\text { Philips Medical } \\
\text { Systems Ltda } \\
\text { (Grupo) } \\
\text { [Adquirente] }\end{array}$ & $\begin{array}{c}\text { Sistemas médicos } \\
\text { Aparelhos domésticos e cuidados } \\
\text { pessoais } \\
\text { Eletrônica de consumo } \\
\text { lluminação } \\
\text { Semicondutores }\end{array}$ & $\begin{array}{c}\text { VMI Industria e Comercio } \\
\text { Ltda } \\
\text { [Adquirida] }\end{array}$ & $\begin{array}{l}\text { Produção e comercialização } \\
\text { de produtos médicos }\end{array}$ & - & - & 2007 & Aquisição \\
\hline 24 & $\begin{array}{c}\text { Cia Providência } \\
\text { Indústria e Comércio } \\
\text { [Adquirente] }\end{array}$ & $\begin{array}{c}\text { Indústria têxtil } \\
\text { Embalagens flexíveis }\end{array}$ & $\begin{array}{c}\text { Isofilme Indústria e } \\
\text { Comércio de Plástico Ltda } \\
\text { [Adquirida] }\end{array}$ & Indústria têxtil & - & - & 2007 & Aquisição \\
\hline 25 & $\begin{array}{l}\text { Cia Brasileira de } \\
\text { Distribuição }\end{array}$ & Varejo & Supermercado Rossi Monza & Varejo & - & - & 2007 & Locação \\
\hline
\end{tabular}

Quadro 2 - Amostra da população

Fonte: elaborado pela autora (dados da pesquisa) 


\subsection{Instrumento(s) de pesquisa}

O instrumento utilizado nesta pesquisa foi uma base de dados elaborada pela própria autora com informações disponíveis em outras bases. Foram utilizados dados financeiros de cinco fontes de informação para a confecção da base.

A primeira fonte de informação foi o sistema interno da SEAE, no qual foi possível obter de maneira mais sistemática e estruturada o número dos atos de concentração utilizados no período da análise (2002 a 2010).

A segunda fonte de informação foi o sítio da SEAE, no qual foi possível observar a classificação de cada ato de concentração e assim identificar aqueles em que houve análise de eficiência.

A terceira fonte foi o sítio da Bovespa, de onde foram extraídas as informações financeiras de grande parte das empresas brasileiras que compunham a amostra.

A quarta fonte de informação foi o sítio de empresas estrangeiras constantes da amostra visando à obtenção de seus dados financeiros. Foi necessário ainda buscar os dados de algumas empresas brasileiras nos respectivos sítios, uma vez que, por alguma razão, não estavam completos no sítio da Bovespa.

E, por fim, a quinta fonte de informação foram os pareceres elaborados pela SEAE, de onde se extraiu a motivação de cada empresa da amostra para utilizar a estratégia de F\&A (economia de escala, economia de escopo, transferência de tecnologia).

A pesquisa consiste, primordialmente, na análise e comparação dos indicadores financeiros das empresas da amostra, a fim de mensurar se, depois de concluída a operação, o resultado financeiro dessas empresas melhorou ou não, analisando, assim, a possível geração de eficiências operacionais. O Quadro 3 compila os indicadores financeiros escolhidos, detalhando a forma de cálculo e o objetivo: 


\begin{tabular}{|c|c|c|c|}
\hline Indicadores & Cálculo & Objetivo & $\begin{array}{c}\text { Eficiência econômica } \\
\text { mensurada }\end{array}$ \\
\hline $\begin{array}{l}\text { Custo da Mercadoria } \\
\text { Vendida (CMV) }\end{array}$ & $\frac{\mathrm{CMV}}{\text { Receita Líquida }(\mathrm{RL})}$ & $\begin{array}{l}\text { Analisar se houve } \\
\text { economia de escala } \\
\text { decorrente de maior } \\
\text { porte e poder de } \\
\text { mercado. }\end{array}$ & Economia de escala \\
\hline $\begin{array}{c}\text { Despesa administrativa } \\
\text { (DA) }\end{array}$ & $\frac{\text { Despesa Administrativa }}{\text { Receita Líquida }}$ & $\begin{array}{c}\text { Verificar se a } \\
\text { integração resultou em } \\
\text { diminuição de } \\
\text { despesas. }\end{array}$ & $\begin{array}{c}\text { - Substituição de } \\
\text { administração } \\
\text { ineficiente; } \\
\text { - Economia de escala; } \\
\text { - Economia de escopo. }\end{array}$ \\
\hline Margem bruta (MB) & $\frac{\text { Lucro Bruto }}{\text { Receita Líquida }}$ & $\begin{array}{l}\text { Analisar se houve } \\
\text { economia de escala } \\
\text { decorrente de maior } \\
\text { porte e poder de } \\
\text { mercado. }\end{array}$ & - Economia de escala \\
\hline Margem líquida (ML) & $\frac{\text { Lucro Líauido }}{\text { Receita Líquida }}$ & $\begin{array}{l}\text { Identificar se as } \\
\text { empresas melhoraram } \\
\text { sua eficiência } \\
\text { operacional, } \\
\text { administrativa e } \\
\text { financeira. }\end{array}$ & $\begin{array}{l}\text { - Substituição de } \\
\text { administração } \\
\text { ineficiente; } \\
\text { - Economia de escala; } \\
\text { - Economia de escopo }\end{array}$ \\
\hline
\end{tabular}

Quadro 3 - Indicadores financeiros utilizados

Fonte: Elaboração própria com base em Pasin e Matias (2001) e Camargos e Barbosa (2005b)

\subsection{Procedimentos de coleta e análise de dados}

No Quadro 2, é possível observar que algumas empresas da amostra fazem parte de um conglomerado (caso da Hermes, que integra o Grupo Jerônimo Martins). Nesses casos, utilizaram-se os dados financeiros do grupo a que pertencem, uma vez que não foi possível obter o dado isolado da empresa.

Após a elaboração da base de dados da pesquisa com as informações disponíveis nas bases descritas na seção 3.3, foi necessário padronizar os dados financeiros 
tendo como parâmetro a moeda corrente do Brasil - o real. Dessa forma, quando as empresas ou grupo envolvidos na operação são estrangeiros e, portanto, possuem seus dados financeiros publicados em outra moeda, foi feita a conversão para o real com base na taxa de câmbio de 6 de janeiro de 2011, publicada no sítio do Banco Central. Houve empresas da amostra com dados publicados nas seguintes moedas: dólar americano, euro, libra e peso mexicano. Para o dólar americano, a taxa de câmbio utilizada foi 1,6860; para o euro, 2,2000; para a libra, 2,5883; e para o peso mexicano, 0,1367 (BACEN).

A análise dos dados se deu sob três perspectivas distintas - análise dos indicadores financeiros, análise de cluster e análise dos pareceres técnicos emitidos pela SEAE.

A primeira perspectiva compara o desempenho de cada indicador financeiro no ano da reestruturação e dois anos após, calculando sua variação. Em seus estudos, Camargos e Barbosa (2005b) e Pasin e Matias (2001) utilizaram escala de tempo semelhante para analisar a geração de eficiências operacionais. Em termos temporais, a pesquisa pode ser visualizada na Figura 1:

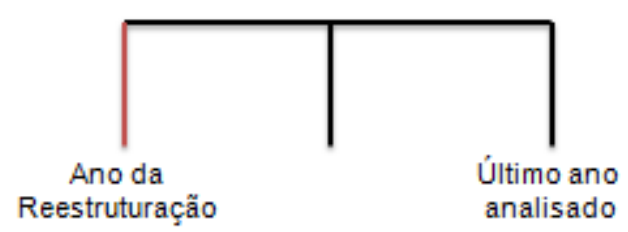

Figura 1 - Linha do tempo relativa à $2^{\underline{a}}$ perspectiva Fonte: elaborado pela autora.

A segunda perspectiva pautou-se pela realização de uma análise de cluster, a qual, segundo Malhotra (2006), tem como objetivo principal classificar objetos em grupos homogêneos tendo como base as variáveis consideradas. Sendo assim, no presente estudo foi realizada com o intuito de observar como as empresas eram agrupadas, calcular o desempenho médio nos indicadores financeiros de cada cluster e ainda analisar se os clusters formados possuíam alguma característica em comum.

Para a análise de cluster, é necessário definir os parâmetros e medidas utilizados para a aglomeração, uma vez que cada um trará agrupamento distinto. A fim de escolher o melhor agrupamento possível, foram feitos dez testes, variando a medida de distância, o procedimento de aglomeração e o método de variância utilizados. 
Após a realização dos testes, observou-se o que havia trazido o melhor agrupamento, definido como o que agrupou o maior número de empresas da amostra. Os parâmetros utilizados no agrupamento utilizado nessa pesquisa foram distância euclidiana como medida de distância, a aglomeração hierárquica como procedimento de aglomeração e o método Ward como método de variância.

A distância euclidiana, que é a raiz quadrada da soma dos quadrados das diferenças dos valores para cada variável, é a medida de distância mais comumente utilizada; a aglomeração hierárquica, por sua vez, caracteriza-se pelo estabelecimento de uma hierarquia ou estrutura em forma de árvore; o método Ward, por fim, é um método de variância bastante utilizado, em que se deve minimizar o quadrado da distância euclidiana às médias dos aglomerados (MALHOTRA, 2006). Além disso, como os resultados dos indicadores financeiros apresentaram uma variação muito grande, desde valores decimais a milhares, os valores foram padronizados, pelo SPSS, em um intervalo de 0 a 1.

Por fim, a análise dos pareceres técnicos emitidos pela SEAE teve o intuito de identificar as motivações das empresas para adotar a estratégia de F\&A, comparando-as com os resultados obtidos pela análise dos indicadores financeiros.

No auxílio da interpretação e análise dos dados, foi utilizado o software Microsoft Exce/ versão 2007 e o software SPSS versão 16.0. 


\section{RESULTADOS E DISCUSSÃO}

Neste capítulo serão apresentados os resultados obtidos por meio da pesquisa realizada no presente estudo e concomitantemente será feita a análise deles à luz da teoria consolidada no Referencial Teórico (Capítulo 2).

Para tanto, o presente capítulo será dividido em seis seções: eficiências operacionais obtidas com base no desempenho do CMV/RL; eficiências operacionais obtidas com base no desempenho da $D A / R L$; eficiências operacionais obtidas com base no desempenho da MB; eficiências operacionais obtidas com base no desempenho da ML; análise de cluster; e comparação das motivações das empresas para a adoção de estratégias de F\&A com os resultados que elas realmente obtiveram nesse processo.

\subsection{Eficiências operacionais obtidas com base no desempenho do CMV/RL}

A análise desse indicador restringiu-se a 34 das 35 empresas que compõem a amostra. A que não foi analisada quanto a esse índice foi a ABN AMRO Holding N.V, um banco, e sua exclusão deveu-se ao fato de os bancos não terem custo da mercadoria vendida.

Do total das 34 empresas analisadas nesse indicador, 52,94\% apresentaram resultado favorável, com destaque para GTI S.A. e Companhia Providência Indústria e Comércio, que exibiram as maiores variações médias percentuais, de $-21,57 \%$ e $14,19 \%$, respectivamente. As demais 16 empresas $(47,06 \%)$ apresentaram piora na variação de seu indicador, destacadamente a Barclays PLC e a Suzano Bahia Sul Papel e Celulose S.A., cujas variações foram de 23,54\% e 16,91\%, respectivamente. As empresas que melhoraram seu desempenho nesse indicador após a reestruturação bem como as que pioraram, com a respectiva variação, podem ser observadas nas Tabelas 2 e 3 , respectivamente: 
É importante frisar que, pela natureza do indicador, a sua medida de variação é quanto menor, melhor, ou seja, se a variação for negativa representa que a empresa foi capaz de melhorar seu desempenho.

Tabela 2 - Empresas que apresentaram melhora no desempenho do CMV/RL

\begin{tabular}{|c|c|c|c|}
\hline Empresa & $A R^{2}$ & $U A^{3}$ & $\begin{array}{l}\text { Variação } \\
\text { (\%) }\end{array}$ \\
\hline GTI S/A & 1,00 & 0,78 & $-21,57$ \\
\hline $\begin{array}{l}\text { Companhia Providência Indústria e } \\
\text { Comércio }\end{array}$ & 0,70 & 0,60 & $-14,19$ \\
\hline Interbrew N.V. S/A & 0,47 & 0,41 & $-11,76$ \\
\hline $\begin{array}{l}\text { Hermes - Sociedade de Investimentos } \\
\text { Mobiliários e Imobiliários Ltda. e } \\
\text { Jerônimo Martins SGPS S.A. }\end{array}$ & 0,87 & 0,79 & $-9,59$ \\
\hline $\begin{array}{l}\text { Braco S.A. Companhia de Bebidas da } \\
\text { Américas - Ambev }\end{array}$ & 0,40 & 0,37 & $-6,86$ \\
\hline Google Inc. & 0,40 & 0,37 & $-6,67$ \\
\hline Hypermarcas S/A & 0,47 & 0,44 & $-5,63$ \\
\hline $\begin{array}{c}\text { Chevron Phillips Chemical Company } \\
\text { LLC }\end{array}$ & 0,93 & 0,89 & $-4,32$ \\
\hline Petrobras Distribuidora S/A & 0,57 & 0,55 & $-3,24$ \\
\hline Companhia Brasileira de Distribuição & 0,73 & 0,71 & $-2,84$ \\
\hline Camargo Corrêa Cimentos S.A & 0,84 & 0,81 & $-2,69$ \\
\hline United Technologies Corporation & 1,04 & 1,01 & $-2,48$ \\
\hline $\begin{array}{l}\text { Americanas.com S.A. Comércio } \\
\text { Eletrônico }\end{array}$ & 0,70 & 0,69 & $-1,32$ \\
\hline Philips Medical Systems Ltda & 0,66 & 0,65 & $-1,24$ \\
\hline Shell Gás (LPG) Brasil S.A. & 0,83 & 0,82 & $-1,08$ \\
\hline Linde Ag. & 0,69 & 0,69 & $-1,00$ \\
\hline Braskem S/A & 0,84 & 0,83 & $-0,97$ \\
\hline Akzo Nobel N.V & 0,61 & 0,61 & $-0,83$ \\
\hline
\end{tabular}

Fonte: elaborada pela autora (dados da pesquisa)

\footnotetext{
${ }^{2}$ AR: ano da reestruturação

${ }^{3}$ UA: último ano analisado (2 anos após a reestruturação)
} 
Tabela 3 - Empresas que apresentaram piora no desempenho do CMV/RL

\begin{tabular}{c|c|c|c}
\hline Empresa & AR & UA & $\begin{array}{c}\text { Variação } \\
\text { (\%) }\end{array}$ \\
\hline Barclays PLC & 0,04 & 0,05 & 23,54 \\
\hline Suzano Bahia Sul Papel Celulose S.A & 0,50 & 0,58 & 16,91 \\
\hline Companhia de Bebidas das Américas & 0,36 & 0,40 & 10,32 \\
\hline Mahle GMBH. & 0,77 & 0,80 & 4,43 \\
\hline Companhia Brasileira de Distribuição & 0,72 & 0,73 & 2,36 \\
\hline International Paper Investiments & 0,74 & 0,75 & 2,18 \\
\hline International Paper do Brasil Ltda. & 0,74 & 0,75 & 2,18 \\
\hline Petróleo Brasileiro S/A - Petrobras & 0,56 & 0,57 & 2,17 \\
\hline Petróleo Brasileiro S/A - Petrobras & 0,56 & 0,57 & 2,17 \\
\hline Carrefour Brasil Comércio e Industria Ltda & 0,78 & 0,79 & 1,30 \\
\hline Refinaria de Petróleo Ipiranga S/A & 0,91 & 0,93 & 1,13 \\
\hline Cia. Ultragaz S.A. & 0,80 & 0,81 & 0,87 \\
\hline Dana Corporation & 0,96 & 0,97 & 0,86 \\
\hline Br Participações e Empreendimentos S.A. & 0,79 & 0,79 & 0,61 \\
\hline Dow Brasil S.A & 0,87 & 0,87 & 0,56 \\
\hline Americanas.com S.A. - Comércio Eletrônico & 0,70 & 0,70 & 0,34 \\
\hline
\end{tabular}

Fonte: elaborado pela autora (dados da pesquisa)

A Tabela 4 apresenta o resultado consolidado das empresas para esse indicador, indicando que houve uma variação de $-0,82 \%$ e, portanto, uma diminuição do CMV quando comparado o último ano analisado com o ano da reestruturação.

Tabela 4 - Desempenho global do CMV/RL

\begin{tabular}{c|c|c|c}
\hline Empresas = 34 & AR & UA & $\begin{array}{c}\text { Variação } \\
(\%)\end{array}$ \\
\hline Índice Consolidado & 0,70 & 0,70 & $-0,82$ \\
\hline
\end{tabular}

Fonte: elaborada pela autora (dados da pesquisa)

Esse resultado favorável indica que, no geral, as empresas foram capazes de obter economia de escala após a reestruturação, derivadas da expansão da quantidade produzida, dados os preços dos insumos.

Segundo Camargos e Barbosa (2004), a maioria dos atos de concentração analisados, sob a óptica financeira e no que tange ao desempenho desse indicador, pode ser classificada como estratégica - motivada pela obtenção de sinergias -, 
uma vez que obtiveram eficiência em economia de escala. Corroborando essa análise, Suen e Kimura (1997) afirmam que as F\&A que visam à obtenção de sinergias são motivadas pelas economias de escala e de escopo.

Essa redução pela obtenção de economia de escala ocorre quando os custos fixos são uma parcela significativa dos custos totais, quando a produtividade do trabalho ou do capital aumenta, quando aumenta o quantum de vendas, quando aumenta 0 poder de barganha frente aos fornecedores (LEMES JR; RIGO; CHEROBIM apud CAMARGOS; BARBOSA, 2005b; Portaria SEAE/SDE no 50, 2001; PASIN; MATIAS, 2001). Não foi possível identificar o motivo da redução do CMV nesse estudo, mas a melhora no desempenho desse indicador pode indicar que a empresa foi capaz de ser eficiente no que tange à obtenção de economia de escala.

Além disso, ao analisar as empresas envolvidas nos atos de concentração (Quadro 2) daquelas que obtiveram os melhores desempenhos nesse indicador, observa-se que os processos podem ser caracterizados como F\&A horizontais, por envolver empresas atuantes em um mesmo setor. Segundo Devos, Kadapakkam e Krishnamurthy (2009), esse tipo de F\&A é motivado essencialmente pela geração de eficiências operacionais e pelo fortalecimento de sua posição de mercado frente aos demais concorrentes.

Por fim, o resultado obtido nesse indicador foi ao encontro do obtido por Pasin e Matias (2001), que em seu estudo também obtiveram melhora nesse indicador, o qual foi analisado sob a mesma metodologia adotada no presente estudo, corroborando a obtenção de economia de escala nos processos de F\&A.

\subsection{Eficiências operacionais obtidas com base no desempenho da DA/RL}

A análise desse indicador abrangeu todas as empresas da amostra (35) e os resultados indicam que $48,57 \%$ melhoraram seu desempenho, enquanto $51,43 \%$ pioraram quanto a esse indicador. Entre as empresas que melhoraram seu desempenho nesse índice, a Camargo Corrêa Cimentos S.A. e a Companhia Providência Indústria e Comércio S.A. apresentaram os melhores resultados, com variação de $-28 \%$ e -27,14\%, respectivamente. Já a Shell Gás (LPG) Brasil S.A. e a 
GTI S.A., cujos desempenhos foram 435,41\% e 113,37\%, respectivamente, tiveram os piores desempenho.

Tanto as empresas que melhoraram seu desempenho nesse indicador, após a reestruturação, como as que pioraram, com a respectiva variação, podem ser observadas nas Tabelas 5 e 6 , respectivamente:

Parece relevante frisar que, pelo mesmo motivo indicado na seção 4.1, a medida de variação desse indicador é quanto menor, melhor, ou seja, a variação negativa representa que a empresa foi capaz de melhorar seu desempenho.

Tabela 5 - Empresas que apresentaram melhora no desempenho da DA/RL

\begin{tabular}{|c|c|c|c|}
\hline Empresa & AR & UA & $\begin{array}{l}\text { Variação } \\
(\%)\end{array}$ \\
\hline Camargo Corrêa Cimentos S.A & 0,13 & 0,09 & $-28,00$ \\
\hline $\begin{array}{c}\text { Companhia Providência Indústria e } \\
\text { Comércio }\end{array}$ & 0,14 & 0,10 & $-27,14$ \\
\hline Philips Medical Systems Ltda. & 0,04 & 0,03 & $-24,55$ \\
\hline $\begin{array}{l}\text { Americanas.com S.A. Comércio } \\
\text { Eletrônico }\end{array}$ & 0,01 & 0,01 & $-17,49$ \\
\hline Dana Corporation & 0,05 & 0,04 & $-16,26$ \\
\hline $\begin{array}{l}\text { Hermes - Sociedade de Investimentos } \\
\text { Mobiliários e Imobiliários Ltda. e } \\
\text { Jerônimo Martins SGPS S.A. }\end{array}$ & 0,04 & 0,03 & $-13,12$ \\
\hline United Technologies Corporation & 0,18 & 0,16 & $-9,88$ \\
\hline Google Inc. & 0,08 & 0,07 & $-8,55$ \\
\hline $\begin{array}{l}\text { Americanas.com S.A. - Comércio } \\
\text { Eletrônico }\end{array}$ & 0,02 & 0,01 & $-8,00$ \\
\hline International Paper Investiments & 0,08 & 0,08 & $-6,67$ \\
\hline International Paper do Brasil Ltda. & 0,08 & 0,08 & $-6,67$ \\
\hline Suzano Bahia Sul Papel Celulose S.A & 0,08 & 0,07 & $-6,20$ \\
\hline Hypermarcas S/A & 0,06 & 0,06 & $-5,91$ \\
\hline Companhia de Bebidas das Américas & 0,10 & 0,09 & $-5,85$ \\
\hline Interbrew N.V. S/A & 0,08 & 0,08 & $-4,93$ \\
\hline Companhia Brasileira de Distribuição & 0,04 & 0,04 & $-2,38$ \\
\hline Linde Ag. & 0,08 & 0,08 & $-0,06$ \\
\hline
\end{tabular}

Fonte: elaborada pela autora (dados de pesquisa) 
Tabela 6 - Empresas que apresentaram piora no desempenho de DA/RL

\begin{tabular}{c|c|c|c}
\hline Empresa & AR & UA & $\begin{array}{c}\text { Variação } \\
(\%)\end{array}$ \\
\hline Shell Gás (LPG) Brasil S.A. & 0,01 & 0,05 & 435,41 \\
\hline GTI S/A & 0,00 & 0,00 & 113,37 \\
\hline Refinaria de Petróleo Ipiranga S/A & 0,03 & 0,05 & 94,59 \\
\hline Braco S.A. Companhia de Bebidas da & 0,05 & 0,09 & 70,80 \\
\hline Américas - Ambev & 0,03 & 0,06 & 58,95 \\
\hline Dow Brasil S.A & & & \\
\hline Chevron Phillips Chemical Company LLC & 0,04 & 0,06 & 45,25 \\
\hline Braskem S/A & & & \\
\hline Akzo Nobel N.V & 0,04 & 0,06 & 31,28 \\
\hline ABN AMRO Holding N.V. & 0,06 & 0,08 & 22,68 \\
\hline Petrobras Distribuidora S/A & 0,49 & 0,57 & 16,28 \\
\hline Companhia Brasileira de Distribuição & 0,03 & 0,03 & 9,08 \\
\hline Mahle GMBH. & 0,03 & 0,03 & 7,72 \\
\hline Petróleo Brasileiro S/A - Petrobras & 0,04 & 0,05 & 7,12 \\
\hline Petróleo Brasileiro S/A - Petrobras & 0,04 & 0,04 & 5,98 \\
\hline Barclays PLC & 0,18 & 0,19 & 5,98 \\
\hline Cia. Ultragaz S.A. & 0,05 & 0,05 & 4,85 \\
\hline Carrefour Brasil Comércio e Indústria Ltda. & 0,16 & 0,17 & 2,74 \\
\hline Br Participações e Empreendimentos S.A. & 0,03 & 0,03 & 1,51 \\
\hline & &
\end{tabular}

Fonte: elaborada pela autora (dados de pesquisa)

A Tabela 7 apresenta o resultado consolidado das empresas para esse indicador, mostrando que houve uma variação de $8,74 \%$, ou seja, um aumento do índice $\mathrm{DA} / \mathrm{RL}$ quando comparado o último ano analisado com o ano da reestruturação.

Tabela 7 - Desempenho global da DA/RL

\begin{tabular}{c|c|c|c}
\hline Empresas $=35$ & AR & UA & $\begin{array}{c}\text { Variação } \\
(\%)\end{array}$ \\
\hline Índice Consolidado & 0,07 & 0,08 & 8,74 \\
\hline
\end{tabular}

Fonte: elaborada pela autora (dados de pesquisa)

Esse indicador apresenta resultado desfavorável, pois indica que, em média, as empresas tiveram um aumento em sua despesa administrativa no último ano analisado quando comparado ao ano de reestruturação. O resultado pode se 
justificar por um inchaço na estrutura administrativa e o consequente aumento de gastos, sobretudo com pessoal, além de indicar que a reestruturação pós-operação pode não ter ocorrido de maneira satisfatória, o que gera custos em detrimento dos ganhos inicialmente previstos.

Consoante essa conclusão, Pasin e Matias (2001) e Key apud Pasin e Matias (2001) mostram que as eficiências operacionais podem nem ocorrer em reorganizações corporativas mal feitas. Significa que a fase de transição da operação, em que as empresas estão de fato se unindo, é a mais crítica do processo e, se não for bem gerenciada, poderá gerar custos em detrimento dos ganhos inicialmente estimados. Assim, quanto mais rápida for feita essa integração, mais rápido surgirão as sinergias. Conclui-se, pois, que as empresas analisadas na amostra não foram capazes de alcançar sinergias gerenciais com base na estratégia de F\&A.

Portanto, ainda que no planejamento da operação estime-se a geração de eficiências operacionais, ou seja, de sinergias, é essencial que esses ganhos sejam mensurados, já que eles podem nem ocorrer em reorganizações corporativas mal feitas (PASIN; MATIAS, 2001).

\subsection{Eficiências operacionais obtidas com base no desempenho da MB}

A análise desse indicador restringiu-se a 34 das 35 empresas que compõem a amostra. A empresa que não foi analisada quanto a esse índice foi a ABN AMRO Holding N.V, um banco, e sua exclusão deveu-se ao fato de os bancos não terem custo da mercadoria vendida e, consequentemente, não apresentarem margem bruta.

Do total das 34 empresas analisadas nesse indicador, 52,94\% apresentaram resultado favorável, com destaque para United Technologies Corporation e Hermes Sociedade de Investimentos Mobiliários e Imobiliários, que exibiram as maiores variações médias percentuais, de $65,28 \%$ e 63,74\%, respectivamente. As demais 16 empresas $(47,06 \%)$ apresentaram piora na variação de seu indicador, 
destacadamente a Cia Ultragaz S.A. e a GTI S.A., cujas variações foram $-196,53 \%$ e - 89,19\%, respectivamente.

Tanto as empresas que melhoraram seu desempenho nesse indicador, após a reestruturação, como as que pioraram, com a respectiva variação, podem ser observadas nas Tabelas 8 e 9, respectivamente:

Tabela 8 - Empresas que apresentaram melhora no desempenho da MB

\begin{tabular}{|c|c|c|c|}
\hline Empresa & AR & UA & $\begin{array}{c}\text { Variação } \\
\text { (\%) }\end{array}$ \\
\hline United Technologies Corporation & $-0,04$ & $-0,01$ & 65,28 \\
\hline $\begin{array}{l}\text { Hermes - Sociedade de Investimentos } \\
\text { Mobiliários e Imobiliários Ltda. e } \\
\text { Jerônimo Martins SGPS S.A. }\end{array}$ & 0,13 & 0,21 & 63,74 \\
\hline $\begin{array}{c}\text { Chevron Phillips Chemical Company } \\
\text { LLC }\end{array}$ & 0,07 & 0,11 & 54,99 \\
\hline $\begin{array}{c}\text { Companhia Providência Indústria e } \\
\text { Comércio }\end{array}$ & 0,30 & 0,40 & 33,02 \\
\hline Camargo Corrêa Cimentos S.A & 0,16 & 0,19 & 13,65 \\
\hline Interbrew N.V. S/A & $-0,53$ & 0,59 & 10,28 \\
\hline Companhia Brasileira de Distribuição & 0,27 & 0,29 & 7,66 \\
\hline Shell Gás (LPG) Brasil S.A. & 0,17 & 0,18 & 5,64 \\
\hline Hypermarcas S/A & 0,53 & 0,56 & 5,01 \\
\hline Braskem S/A & 0,16 & 0,17 & 4,95 \\
\hline $\begin{array}{c}\text { Braco S.A. Companhia de Bebidas da } \\
\text { Américas - Ambev }\end{array}$ & 0,60 & 0,63 & 4,54 \\
\hline Google Inc. & 0,60 & 0,63 & 4,46 \\
\hline Petrobras Distribuidora S/A & 0,43 & 0,45 & 4,26 \\
\hline $\begin{array}{c}\text { Americanas.com S.A. Comércio } \\
\text { Eletrônico }\end{array}$ & 0,30 & 0,31 & 3,05 \\
\hline Philips Medical Systems Ltda. & 0,34 & 0,35 & 2,41 \\
\hline Linde Ag. & 0,31 & 0,31 & 2,28 \\
\hline $\begin{array}{l}\text { Carrefour Brasil Comércio e Indústria } \\
\qquad \text { Ltda }\end{array}$ & 0,22 & 0,23 & 1,74 \\
\hline Akzo Nobel N.V & 0,39 & 0,39 & 1,31 \\
\hline
\end{tabular}

Fonte: elaborada pela autora (dados da pesquisa) 
Tabela 9 - Empresas que apresentaram piora no desempenho da MB

\begin{tabular}{|c|c|c|c|}
\hline Empresa & AR & UA & $\begin{array}{l}\text { Variação } \\
\text { (\%) }\end{array}$ \\
\hline Cia. Ultragaz S.A. & 0,20 & $-0,19$ & $-196,52$ \\
\hline GTI S/A & 2,00 & 0,22 & $-89,19$ \\
\hline Dana Corporation & 0,04 & 0,03 & $-20,86$ \\
\hline Suzano Bahia Sul Papel Celulose S.A & 0,50 & 0,42 & $-16,68$ \\
\hline Mahle GMBH. & 0,23 & 0,20 & $-14,90$ \\
\hline Refinaria de Petróleo Ipiranga S/A & 0,09 & 0,07 & $-12,11$ \\
\hline International Paper Investiments & 0,26 & 0,25 & $-6,17$ \\
\hline International Paper do Brasil Ltda. & 0,26 & 0,25 & $-6,17$ \\
\hline Companhia Brasileira de Distribuição & 0,28 & 0,27 & $-5,95$ \\
\hline Companhia de Bebidas das Américas & 0,64 & 0,60 & $-5,80$ \\
\hline Dow Brasil S.A & 0,13 & 0,13 & $-3,69$ \\
\hline Petróleo Brasileiro S/A - Petrobras & 0,44 & 0,43 & $-2,71$ \\
\hline Petróleo Brasileiro S/A - Petrobras & 0,44 & 0,43 & $-2,71$ \\
\hline Br Participações e Empreendimentos S.A. & 0,21 & 0,21 & $-2,25$ \\
\hline Barclays PLC & 0,96 & 0,95 & $-1,01$ \\
\hline $\begin{array}{c}\text { Americanas.com S.A. - Comércio } \\
\text { Eletrônico }\end{array}$ & 0,30 & 0,30 & $-0,77$ \\
\hline
\end{tabular}

Fonte: elaborada pela autora (dados da pesquisa)

A Tabela 10 apresenta o resultado consolidado das empresas para esse indicador, mostrando que houve uma variação de $4,47 \%$ e, dessa forma, um aumento da MB quando comparado o último ano analisado com o ano da reestruturação.

Tabela 10 - Desempenho global da MB

\begin{tabular}{c|c|c|c}
\hline Empresas = 34 & AR & UA & $\begin{array}{c}\text { Variação } \\
\text { (\%) }\end{array}$ \\
\hline Índice Consolidado & 0,29 & 0,30 & 4,47 \\
\hline
\end{tabular}

Fonte: elaborada pela autora 
Pela própria definição do cálculo do Lucro Bruto (Receita líquida de vendas - Custo da Mercadoria Vendida), utilizado para a obtenção do índice de margem bruta, os resultados do índice de margem bruta e de CMV estão intimamente relacionados, de modo que, se um obtiver resultado favorável, o outro provavelmente também obterá. É o que se observa no presente estudo - tanto o CMV quanto a MB apresentaram resultados favoráveis para as empresas da amostra. Essa melhora sinaliza que as empresas analisadas apresentaram maior eficiência no controle e gestão da sua estrutura de custos, obtendo assim economias de escala, em virtude provavelmente de maior porte e poder de barganha (CAMARGOS; BARBOSA, 2005b).

Além dessas razões, a economia de escala pode ser obtida ainda quando (a) os custos fixos representam parcela significativa dos custos totais, (b) há aumento da produtividade do trabalho ou do capital e (c) há aumento do quantum de vendas (LEMES JR; RIGO; CHEROBIM apud CAMARGOS; BARBOSA, 2005b; Portaria SEAE/SDE no 50, 2001; PASIN; MATIAS, 2001).

O resultado favorável para o indicador de MB também foi obtido em seu estudo por Camargos e Barbosa (2005b), corroborando o resultado e a análise desse indicador no presente estudo.

\subsection{Eficiências operacionais obtidas com base no desempenho da ML}

A análise desse indicador abrangeu todas as empresas da amostra (35), e os resultados indicam que $64,71 \%$ melhoraram seu desempenho, enquanto $35,29 \%$ pioraram quanto a esse indicador. Entre as empresas que melhoraram seu desempenho nesse índice, a Refinaria de Petróleo Ipiranga S.A. e a Companhia Providência Indústria e Comércio apresentaram os melhores resultados, com uma variação de $141.518,19 \%$ e 1.065,98\%, respectivamente. Já a International Papel Investments e a International Paper do Brasil Ltda., cujo desempenho foi 208,16\% para ambas, tiveram os piores resultados. 
Tanto as empresas que melhoraram seu desempenho nesse indicador, após a reestruturação, como as que pioraram, com sua respectiva variação, podem ser observadas nas Tabelas 11 e 12, respectivamente:

Tabela 11 - Empresas que apresentaram melhora no desempenho da ML

\begin{tabular}{|c|c|c|c|}
\hline Empresa & AR & UA & $\begin{array}{l}\text { Variação } \\
(\%)\end{array}$ \\
\hline Refinaria de Petróleo Ipiranga S/A & 0,01 & 12,93 & $141.518,19$ \\
\hline $\begin{array}{c}\text { Companhia Providência Indústria e } \\
\text { Comércio }\end{array}$ & 0,01 & 0,14 & $1.065,98$ \\
\hline Linde Ag. & 0,03 & 0,15 & 408,05 \\
\hline $\begin{array}{l}\text { Braco S.A. Companhia de Bebidas da } \\
\text { Américas - Ambev }\end{array}$ & 0,10 & 0,27 & 179,49 \\
\hline $\begin{array}{c}\text { Hermes - Sociedade de } \\
\text { Investimentos Mobiliários e } \\
\text { Imobiliários Ltda. e Jerônimo Martins } \\
\text { SGPS S.A. }\end{array}$ & $-0,05$ & 0,04 & 171,34 \\
\hline GTI S/A & 0,06 & 0,14 & 159,97 \\
\hline Companhia de Bebidas das Américas & 0,24 & 0,53 & 121,29 \\
\hline Companhia Brasileira de Distribuição & 0,02 & 0,04 & 111,56 \\
\hline Interbrew N.V. S/A & 0,08 & 0,16 & 90,37 \\
\hline $\begin{array}{l}\text { Carrefour Brasil Comércio e Indústria } \\
\text { Ltda. }\end{array}$ & 0,02 & 0,03 & 58,69 \\
\hline $\begin{array}{l}\text { Br Participações e Empreendimentos } \\
\text { S.A. }\end{array}$ & $-0,02$ & $-0,01$ & 56,49 \\
\hline Hypermarcas S/A & 0,10 & 0,15 & 49,93 \\
\hline Braskem S/A & 0,04 & 0,07 & 47,37 \\
\hline Companhia Brasileira de Distribuiç̧ão & 0,03 & 0,04 & 36,02 \\
\hline Shell Gás (LPG) Brasil S.A. & 0,06 & 0,08 & 33,63 \\
\hline $\begin{array}{c}\text { Chevron Phillips Chemical Company } \\
\text { LLC }\end{array}$ & 0,06 & 0,07 & 27,54 \\
\hline Petróleo Brasileiro S/A - Petrobras & 0,17 & 0,22 & 25,85 \\
\hline Petróleo Brasileiro S/A - Petrobras & 0,17 & 0,22 & 25,85 \\
\hline Camargo Corrêa Cimentos S.A & 0,31 & 0,36 & 16,37 \\
\hline Google Inc. & 0,25 & 0,28 & 8,83 \\
\hline United Technologies Corporation & 0,10 & 0,11 & 6,77 \\
\hline Petrobras Distribuidora S/A & 0,21 & 0,22 & 4,93 \\
\hline Cia. Ultragaz S.A. & 0,06 & 0,06 & 3,49 \\
\hline
\end{tabular}

Fonte: elaborada pela autora (dados da pesquisa) 
Tabela 12 - Empresas que apresentaram piora no desempenho da ML

\begin{tabular}{|c|c|c|c|}
\hline Empresa & AR & UA & $\begin{array}{l}\text { Variação } \\
\text { (\%) }\end{array}$ \\
\hline International Paper Investiments & 0,05 & $-0,05$ & $-208,16$ \\
\hline International Paper do Brasil Ltda. & 0,05 & $-0,05$ & $-208,16$ \\
\hline ABN AMRO Holding N.V. & 0,44 & $-0,33$ & $-175,43$ \\
\hline Akzo Nobel N.V & 0,92 & 0,03 & $-97,16$ \\
\hline Mahle GMBH. & 0,04 & 0,00 & $-90,21$ \\
\hline Philips Medical Systems Ltda. & 0,17 & 0,02 & $-89,48$ \\
\hline Dow Brasil S.A & 0,06 & 0,02 & $-73,06$ \\
\hline $\begin{array}{c}\text { Americanas.com S.A. - Comércio } \\
\text { Eletrônico }\end{array}$ & 0,08 & 0,03 & $-61,17$ \\
\hline $\begin{array}{c}\text { Americanas.com S.A. Comércio } \\
\text { Eletrônico }\end{array}$ & 0,05 & 0,02 & $-51,53$ \\
\hline Suzano Bahia Sul Papel Celulose S.A & 0,30 & 0,17 & $-43,43$ \\
\hline Barclays PLC & 0,86 & 0,70 & $-18,29$ \\
\hline Dana Corporation & $-0,09$ & $-0,09$ & $-5,14$ \\
\hline
\end{tabular}

Fonte: elaborada pela autora (dados da pesquisa)

A Tabela 13 apresenta o resultado consolidado das empresas para esse indicador, mostrando que houve uma variação de $-13,87 \%$, o que leva a uma diminuição da $\mathrm{ML}$ quando comparado o último ano analisado com o ano da reestruturação.

Tabela 13 - Desempenho global da ML

\begin{tabular}{c|c|c|c}
\hline Empresas = 35 & AR & UA & $\begin{array}{c}\text { Variação } \\
\text { (\%) }\end{array}$ \\
\hline Índice Consolidado & 0,14 & 0,12 & $-13,87$ \\
\hline
\end{tabular}

Fonte: elaborada pela autora (dados de pesquisa)

A piora no desempenho desse indicador revela que as empresas analisadas não conseguiram amenizar o possível impacto decorrente do aumento de suas despesas administrativa e gerais, o que reduz a rentabilidade para seus acionistas, embora tenham demonstrado maior eficiência após a troca de controle gerencial, com maior vigilância sobre seus custos operacionais, evidenciado pela melhora nos indicadores 
de CMV e MB (CAMARGOS; BARBOSA, 2005b). Os resultados obtidos no presente estudo vão de encontro aos obtidos por Camargo e Barbosa (2005b), mas o presente estudo não pôde identificar as razões para tal divergência.

\subsection{Análise de Cluster}

A análise de cluster, segundo Malhotra (2006), tem como objetivo principal classificar objetos em grupos homogêneos tendo como base as variáveis consideradas.

Dessa forma, a análise de cluster foi feita com o intuito de identificar a existência de algum padrão no agrupamento das empresas da amostra, e assim avaliar se o desempenho em cada uma das variáveis - CMV/RL, DA/RL, MB e ML - é influenciado, de alguma forma, pelo ano da ocorrência do ato de concentração, pelo setor de atuação das empresas envolvidas, pela nacionalidade das empresas ou por sua posição na operação, em caso de aquisição - adquirente ou adquirida.

A análise de clusters no presente estudo está representada pelo dendograma (Figura 2). Na análise de clusters, estabeleceu-se nova ordem entre as empresas da amostra, de modo a formar grupos. Considerando esses resultados, o corte foi feito entre 5 e 10 (linkage distance), pois se observou que, com esse corte, era obtido um menor número de grupos, mas que ainda mantinham relativa homogeneidade entre si. Foram formados, portanto, 4 grupos. 
Labe1

Petroleo Brasileiro S/A - Petrobras

Petroleo Brasileiro S/A - Petrobras

International Paper Investiments

International Paper do Brasil Ltda.

Br Participações e Empreendimentos S.A.

Carrefour Brasil Comércio e Industria Ltda

Companhia Brasileira de Distrlibuição

Dana Corporation

Companhia de Bebidas das Americas

Google Inc.

Petrobras Distribuidora $S / A$

Companhia Brasileira de Distribuição

Linde Ag.

Philips Medical Systems Ltda

Americanas.com S.A. Comércio Eletrônico

Americanas.com S.A. - Comércio Eletrônico

Hypermarcas S/A

Akzo Nobel N.V

Dow Brasil S.A

Braskem $S / A$

Braco S.A. Companhia de Bebidas da Américas - AMBEV

Chevron Ph.illips Chemical Company LLC

United Technologies Corporation

Hermes - Sociedade de Investimentos Mobiliários e Imobiliários

Companhia Providência Indústria e Comércio

Suzano Bahia Sul Papel Celulose S.A

Barclays PLC

Mahle GMBH.

Camargo Corrêa Cimentos S.A

Cia. Ultragaz S.A.

GII $S / \mathbb{A}$

Interbrew N.V. S/A

Shell Gás (LPG) Brasil S.A.

Refinaria de Petroleo Ipiranga $S / A$

Figura 2 - Dendograma obtido na análise de cluster

Fonte: elaborado pela autora (dados da pesquisa)
5

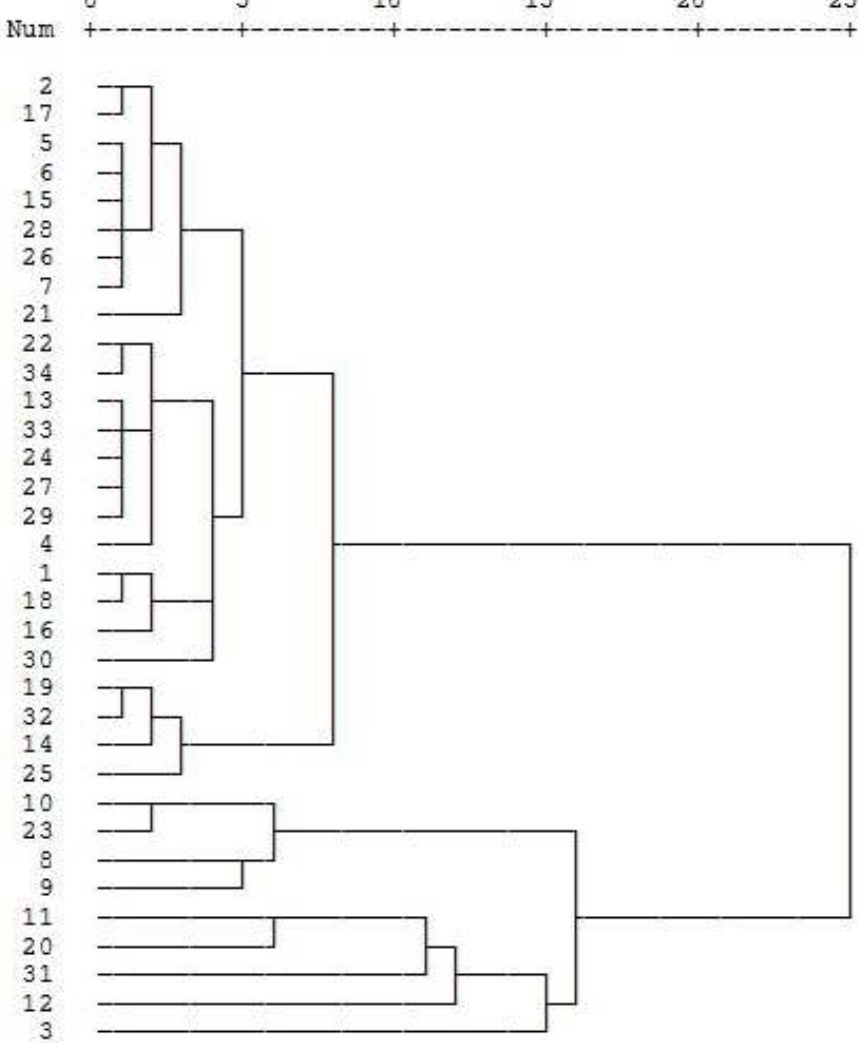

Os grupos foram analisados segundo o comportamento frente aos indicadores definidos na pesquisa - CMV/RL, DA/RL, $M B$ e $M L-$, representados como a média do desempenho das empresas componentes de cada cluster. O desempenho de cada cluster e seu resultado constam das Tabelas 14 e 15, respectivamente:

Tabela 14 - Valores médios dos grupos em relação ao desempenho de cada variável

\begin{tabular}{|c|c|c|c|c|}
\hline & CMV/RL & DA/RL & MB & ML \\
\cline { 2 - 5 } & AR $\times$ UA & AR $\times$ UA & AR $\times$ UA & AR $\times$ UA \\
\hline 1ํ cluster (21 casos) & $-0,26$ & 5,44 & $-0,73$ & 16,21 \\
\hline $2^{\circ}$ cluster (4 casos) & $-7,64$ & $-1,22$ & 54,26 & 317,91 \\
\hline 3o cluster (3 casos) & 14,96 & 2,08 & $-10,87$ & $-50,64$ \\
\hline $4^{\circ}$ c cluster (2 casos) & $-10,35$ & 59,11 & $-142,86$ & 81,73 \\
\hline
\end{tabular}

Fonte: elaborada pela autora (dados da pesquisa) 
Tabela 15 - Resultado dos grupos

\begin{tabular}{|c|c|c|c|c|}
\hline & CMV/RL & DA/RL & MB & ML \\
\cline { 2 - 5 } & AR x UA & AR x UA & AR x UA & AR x UA \\
\hline 1 cluster (21 casos) & Melhorou & Piorou & Piorou & Melhorou \\
\hline 2 cluster (4 casos) & Melhorou & Melhorou & Melhorou & Melhorou \\
\hline 3 cluster (3 casos) & Piorou & Piorou & Piorou & Piorou \\
\hline 4 cluster (2 casos) & Melhorou & Piorou & Piorou & Melhorou \\
\hline
\end{tabular}

Fonte: elaborada pela autora (dados da pesquisa)

Verifica-se que $75 \%$ dos grupos apresentaram melhora nos indicadores de CMV/RL e ML, enquanto apenas $25 \%$ apresentaram melhora nos indicadores de DA/RL e MB. Isso indica que as empresas foram capazes de ter maior eficiência no controle de seus custos operacionais, com a redução do $\mathrm{CMV} / \mathrm{RL}$, entretanto não conseguiram amenizar um possível impacto decorrente do aumento de despesas administrativa e gerais, observado pelo aumento da DA/RL. Ainda assim, conseguiram aumentar a rentabilidade de seus acionistas. Dessa forma, é possível concluir que as empresas envolvidas em processos de F\&A foram eficientes no alcance de sinergias operacionais, acontecendo o contrário no que se refere às sinergias gerenciais (CAMARGOS; BARBOSA, 2005b).

O grupo 1, que englobou o maior número de casos, apresentou melhora nos indicadores de CMV/RL e ML e piora nos dois restantes, sendo que $42,86 \%$ desse grupo é composto por empresas de varejo. Essa constatação pode indicar uma possível relação entre o resultado dos indicadores e o setor da empresa, o qual não pôde ser verificado no presente estudo porque extrapola o escopo definido.

O perfil das empresas do grupo 2, que apresentou melhora em todos os seus indicadores, indica que $75 \%$ das empresas são internacionais. Dessa forma, é possível constatar que elas utilizaram a estratégia cross border, visando à internacionalização, ou seja, entrar no mercado de um país que não o seu. As vantagens do uso de tal estratégia são eliminar alguns aspectos bastante onerosos para a adquirente, como a compreensão da cultura e estudo do mercado local, instalação de planta, entre outros (ANSOFF; MC DONNELL, 2009).

Já as empresas do grupo 3, o qual piorou em todos os seus indicadores, mostra que 100\% das empresas cujo processo consistiu em aquisição são adquirentes, o que vai ao encontro de estudos (KAYO et al., 2009; CAMARGOS; BARBOSA, 2007; 
BRITO et al., 2005) que comprovam que as F\&A geram ganhos positivos para os acionistas da empresa adquirida, com resultados não significativos ou mesmo negativos para os acionistas das adquirentes.

\subsection{Motivação para adoção da estratégia de F\&A x sinergias observadas}

A presente seção visa identificar as motivações das empresas da amostra para a realização da estratégia de $F \& A$, seja economia de escala, de escopo, transferência de tecnologia, contrastando com os resultados obtidos nos indicadores analisados no presente estudo, a fim de certificar se os ganhos previstos para realização da operação foram efetivamente concretizados. Essas informações podem ser visualizadas no Quadro 4, e as empresas que apresentaram congruência, nos indicadores analisados, entre a motivação e a eficiência econômica obtida estão destacadas em negrito:

\begin{tabular}{|c|c|c|c|}
\hline & Empresa & Motivação para F\&A & Eficiência econômica obtida \\
\hline 01 & Cia Brasileira de Distribuição & $\begin{array}{c}\text { Despesa administrativa } \\
\text { Economia de escala } \\
\text { Economia de escopo } \\
\text { Introdução de novas tecnologias }\end{array}$ & $\begin{array}{l}\text { Custo da mercadoria vendida } \\
\text { Despesa administrativa } \\
\text { Margem bruta } \\
\text { Margem líquida }\end{array}$ \\
\hline 02 & $\begin{array}{l}\text { Hermes } \\
\text { (Grupo) }\end{array}$ & $\begin{array}{c}\text { Despesa administrativa } \\
\text { Economia de escala } \\
\text { Economia de escopo } \\
\text { Introdução de novas tecnologias }\end{array}$ & $\begin{array}{l}\text { Custo da mercadoria vendida } \\
\text { Despesa administrativa } \\
\text { Margem bruta } \\
\text { Margem líquida }\end{array}$ \\
\hline 03 & $\begin{array}{l}\text { Br Participações e Empreendimentos } \\
\text { (Grupo) }\end{array}$ & $\begin{array}{l}\text { Economia de escala } \\
\text { Transferência de tecnologia }\end{array}$ & Margem líquida \\
\hline 04 & $\begin{array}{l}\text { Cia Ultragaz S.A. } \\
\text { (Grupo) }\end{array}$ & Economia de escala & Margem líquida \\
\hline 06 & Suzano Bahia Sul Papel e Celulose & $\begin{array}{l}\text { Economia de escala } \\
\text { Economia de escopo }\end{array}$ & Despesa administrativa \\
\hline 07 & $\begin{array}{c}\text { Braco S.A. Cia de Bebidas da Américas - } \\
\text { Ambev }\end{array}$ & Dados confidenciais & $\begin{array}{l}\text { Custo da mercadoria vendida } \\
\text { Margem bruta } \\
\text { Margem líquida }\end{array}$ \\
\hline
\end{tabular}




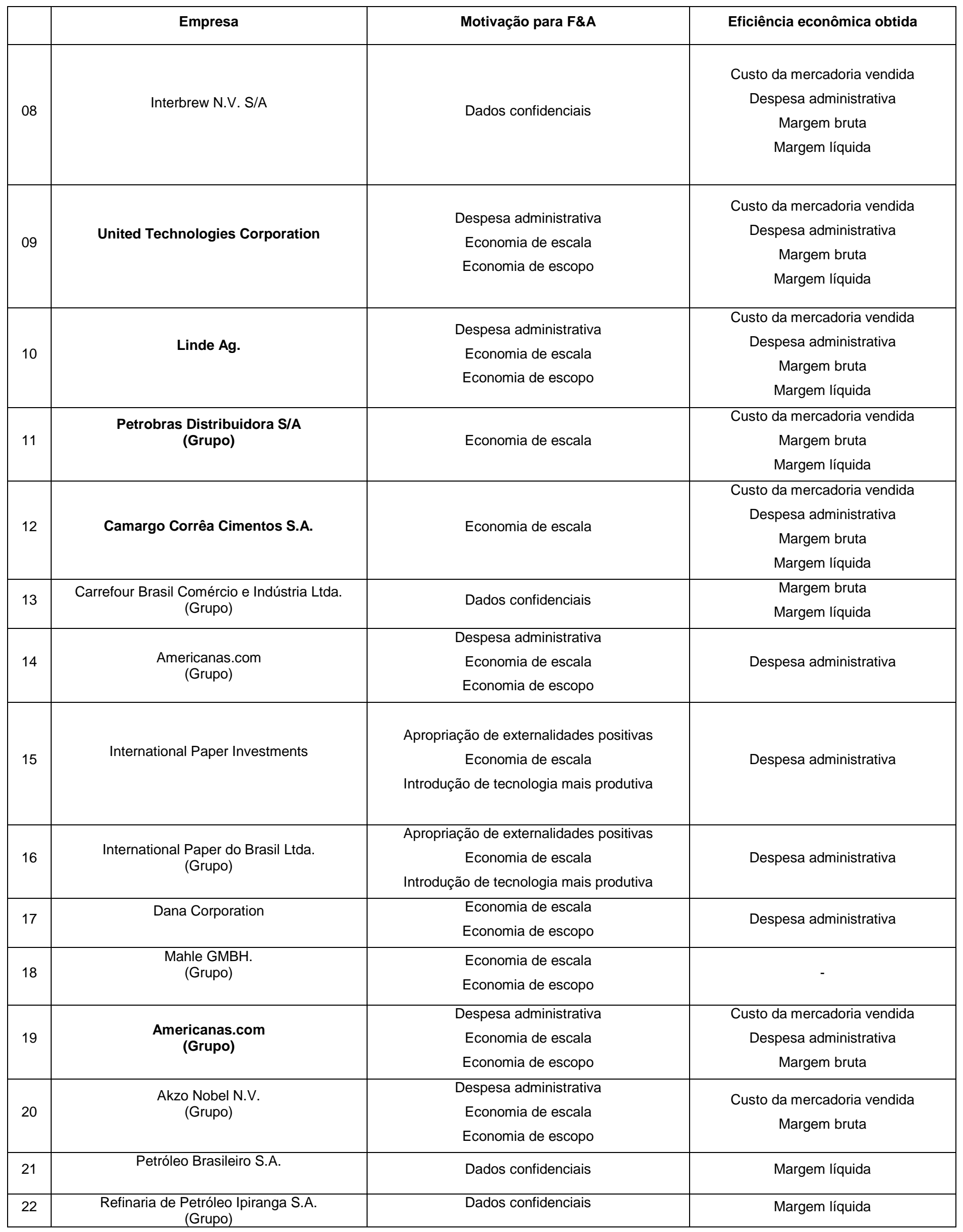




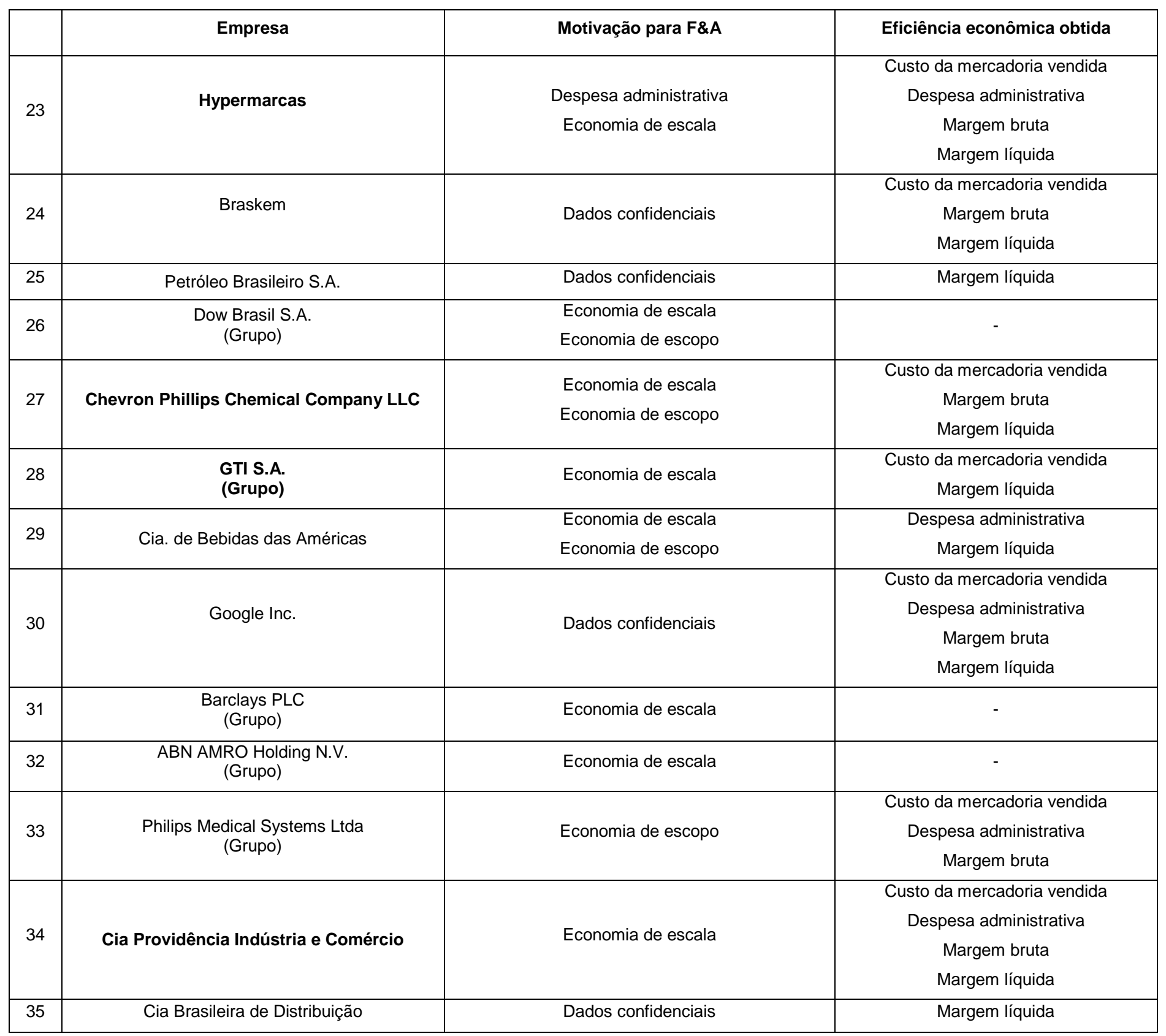

Quadro 4 - Motivação x Eficiência operacional obtida

Fonte: elaborado pela autora (dados da pesquisa)

Relativamente a nove empresas da amostra não foi possível comparar a motivação para F\&A e as eficiências operacionais obtidas, pois as informações foram classificadas como confidenciais pelas requerentes.

Ao limitar a comparação às 26 empresas restantes, 46,16\% apresentaram congruência entre a motivação para $F \& A$ e as eficiências operacionais obtidas, indicando a dificuldade para verificar e quantificar os incrementos de eficiência, em parte porque as informações necessárias se referem a eventos futuros (Portaria SEAE/SDE no 50, 2001, SAMUELS et al., 1990). Dessa forma, F\&A de empresa 
pode ser uma excelente oportunidade para expandir e consolidar uma posição mais relevante no mercado, todavia não deve ser considerada uma alternativa simples, pois traz consigo muitos riscos embutidos e difíceis de prever (OLIVEIRA; FORTE; RAGÃO, 2007).

Através da comparação é possível observar ainda que as empresas que elencaram introdução de nova tecnologia como motivação não foram capazes de concretizá-la na prática. Dentre os motivos para ocorrência dessa incongruência cabe citar a limitação quanto aos indicadores do presente estudo em captar essa eficiência; o retorno mais a longo prazo esperado por um investimento em tecnologia da informação; e ainda a alegação desse motivo pelas empresas envolvidas no ato de concentração somente para constar como possível eficiência da operação, não sendo efetivamente esperada na prática. 


\section{CONCLUSÕES E RECOMENDAÇÕES}

O acirramento da concorrência e a necessidade de as organizações firmarem uma posição no mercado têm levado muitas empresas a adotar estratégias de $F \& A$, seja simplesmente para proteger-se contra os concorrentes ou substituir administração ineficiente, seja para gerar sinergias e eficiências operacionais (CAMARGOS; BARBOSA, 2005a; SUEN; KIMURA, 1997).

Tendo em vista o aumento do número de atos de concentração nos últimos anos e falta de consenso na literatura quanto à geração ou não de sinergias nesses processos, o objetivo geral do presente trabalho foi analisar as eficiências operacionais decorrentes do processo de F\&A de empresas. Para isso, procedeu-se ao estudo dos atos de concentração notificados entre 2002 e 2008 , com a análise de eficiências operacionais envolvendo empresas de capital aberto.

Das empresas analisadas, 52,94\% apresentaram redução do índice CMV/RL, e algumas reduções alcançaram até $21,57 \%$, com a redução média de $0,82 \%$. A redução desse índice pode decorrer do aumento de poder de barganha com os fornecedores, aumento da quantidade de vendas, indicando que as empresas aumentaram sua eficiência econômica pela economia de escala (LEMES JR; RIGO; CHEROBIM apud CAMARGOS; BARBOSA, 2005b; Portaria SEAE/SDE nº 50, 2001; PASIN; MATIAS, 2001).

Quanto ao índice DA/RL, 51,43\% das empresas apresentaram resultados negativos, ou seja, a reestruturação corporativa e a mudança de gestão aumentaram as despesas administrativa e gerais dessas empresas. Dessa forma, as empresas apresentaram ineficiências na etapa de reestruturação administrativa, fase crítica do processo de F\&A, incorrendo em aumento de custos, com prejuízo para as sinergias e eficiências operacionais inicialmente previstas (PASIN; MATIAS, 2001; KEY apud PASIN; MATIAS, 2001).

No que se refere ao índice de MB, 52,94\% das empresas analisadas apresentaram resultado favorável, corroborando a melhora do índice CMV/RL e sinalizando maior eficiência no controle e gestão da estrutura de custos, com economia de escala em virtude de maior porte e poder de barganha (CAMARGOS; BARBOSA, 2005b). 
Por fim, o último índice analisado, ML, mostra que, na média, as empresas apresentaram redução de $13,87 \%$, o que revela queda de rentabilidade para os acionistas, e passaram a ter, em última instância, menor eficiência após a troca do controle gerencial (CAMARGOS; BARBOSA, 2005b).

Portanto, entre as eficiências operacionais analisadas, foi possível identificar, pelo presente estudo, sinergia no que se refere à economia de escala. Isso indica que os processos de F\&A são capazes de aumentar o poder de barganha das empresas e diminuir o custo da mercadoria vendida, o que pode acarretar, em consequência, redução do preço final para o consumidor.

Foi possível verificar ainda que a minoria $(46,16 \%)$ das empresas apresentou congruência entre as sinergias e eficiências operacionais previstas quando da notificação do ato de concentração ao SBDC e as efetivamente obtidas, segundo os indicadores financeiros analisados. Esse resultado corrobora os riscos inerentes ao processo de F\&A e a dificuldade de prever os ganhos da operação, por referir-se a eventos futuros, fazendo com que, na maioria dos casos analisados, os ganhos inicialmente previstos tenham se transformado em custos e despesas para as empresas envolvidas (OLIVEIRA; FORTE; RAGÃO, 2007; Portaria SEAE/SDE ํo 50, 2001, SAMUELS et al., 1990).

Apesar de ter alcançado seu objetivo, o trabalho enfrentou algumas limitações, a exemplo da dificuldade de acesso aos dados completos, o que acabou por restringir bastante o universo da pesquisa.

Deve-se ponderar que os resultados conseguidos, embora não possam ser estendidos a todo o mercado, porque a pesquisa se restringiu a uma parcela de F\&A ocorridas no período analisado, constituem um bom sinalizador de que as empresas podem gerar economia de escala.

Para pesquisas futuras, sugere-se não só a ampliação da unidade temporal, a fim de verificar se as sinergias para os processos de F\&A ocorrem mais a longo prazo, como também a utilização de outros indicadores capazes de identificar a geração de sinergias e o resultado da situação econômico-financeira das empresas envolvidas na operação. 


\section{REFERÊNCIAS}

ANSOFF, H. Igor; MCDONNELL, Edward J. Implantando a administração estratégica. 1. ed. São Paulo: Atlas, 2009, 590 p.

BANCO CENTRAL DO BRASIL. Disponível em: <http://www.bcb.gov.br>. Acesso em: 06 jan. 2011.

BETHLEM, Agrícola. O crescimento das empresas brasileiras - algumas considerações sobre causas e efeitos. Revista de Administração de Empresas, São Paulo, v. 35, n. 1, p. 6-13, 2005.

BRASIL. Portaria conjunta SEAE/SDE n 50, de 1ํ de agosto de 2001.

BRASIL. Constituição (1988). Constituição da República Federativa do Brasil: 1988 - texto constitucional de 5 de outubro de 1988, com as alterações adotadas pelas Emendas Constitucionais de n. 1, de 1992, a 53, de 2006, e pelas Emendas Constitucionais de Revisão de n. 1 a 6, de 1994 - 27 ed. - Brasília: Câmara dos Deputados, Coordenação de Publicações, 2007.

BRASIL. Lei $\mathbf{n}$ 0 6.404, de 15 de dezembro de 1976. Disponível em: $<$ http://www.planalto.gov.br/ccivil_03/Leis/L6404consol.htm>. Acesso em: 19 nov. 2010.

BRESMAN, H.; BIRKINSHAW, J; NOBEL, R. Knowledge transfer in international acquisitions. Journal of International Business Studies, Washington, v. 30, n. 3, p. 439-462, 1999.

BRITO, Giovani Antônio Silva; BATISTELLA, Flávio Donizete; FAMÁ, Rubens. Fusões e aquisições no setor bancário: avaliação empírica do efeito sobre o valor das ações. Revista de Administração da Universidade de São Paulo, São Paulo, v. 40, n. 4 , p. 353-360, 2005.

CAMARGOS, Marcos Antônio de; BARBOSA, Francisco Vidal. Fusões, aquisições e takeovers: um levantamento teórico dos motivos, hipóteses testáveis e evidências empíricas. Revista de Gestão da Universidade de São Paulo, São Paulo, v. 10, n. 2, p. 17-38, 2003.

CAMARGOS, Marcos Antônio de; BARBOSA, Francisco Vidal. Acordo de fusão TAM-VARIG: um estudo de caso dos fatores estratégicos, mercadológicos e 
financeiros e seus impactos sobre os stakeholders. Revista de Gestão da Universidade de São Paulo, São Paulo, v. 11, n. 4, p. 75-91, 2004.

CAMARGOS, Marcos Antônio de; BARBOSA, Francisco Vidal. Da fusão Antárctica/Brahma à fusão com Interbrew: Uma análise da trajetória econômicofinanceira e estratégica da Ambev. Revista de Gestão da Universidade de São Paulo, São Paulo, v. 12, n. 3, p. 47-63, 2005a.

CAMARGOS, Marcos Antônio de; BARBOSA, Francisco Vidal. Análise do desempenho econômico-financeiro e da criação de sinergias em processos de fusões e aquisições do mercado brasileiro ocorridos entre 1995 e 1999. Revista de Gestão da Universidade de São Paulo, São Paulo, v. 12, n. 2, p. 99-115, 2005b.

CAMARGOS, Marcos Antônio de; BARBOSA, Francisco Vidal. Eficiência informacional do mercado de capitais brasileiro pós-Plano Real: um estudo de eventos dos anúncios de fusões e aquisições. Revista de Administração da Universidade de São Paulo, São Paulo, v. 41, n. 1, p. 43-58, 2006.

CAMARGOS, Marcos Antônio de; BARBOSA, Francisco Vidal. Análise empírica da reação do mercado de capitais brasileiro aos anúncios de fusões e aquisições ocorridos entre 1994 e 2001. Revista de Administração da Universidade de São Paulo, São Paulo, v. 42, n. 4, p. 468-481, 2007.

CAMARGOS, Marcos Antônio de; BARBOSA, Francisco Vidal. Fusões e aquisições de empresas brasileiras: criação de valor e sinergias operacionais. Revista de Administração de Empresas, São Paulo, v. 49, n. 2, p. 206-220, 2009.

CAMARGOS, Marcos Antônio de; ROMERO, Julio Alfredo Racchumi. Análise empírica da reação do mercado de capitais brasileiro a eventos corporativos: este conjunto da hipótese de eficiência do mercado. Revista de Gestão da Universidade de São Paulo, São Paulo, v. 13, n. 3, p. 57-74, 2006.

CONSELHO ADMINISTRATIVO DE DEFESA ECONÔMICA. Disponível em: <http://www.cade.gov.br/>. Acesso em: 19 nov. 2010.

DEVOS, Erick; KADAPAKKAM, Palani-Rajan; KRISHNAMURTHY, Srinivasan. How do mergers create value? A comparison of taxes, market power and efficiency improvements as explanations for synergies. The Review of Financial Studies, Oxford, v. 22, n. 3, p. 1179-1211, 2009.

DICKERSON, Andrew P.; GIBSON, Heather D.; TSAKALOTOS, Euclid. The impact of acquisitions on company performance: evidence from a large panel of UK firms. Oxford Economic Papers, Oxford, v. 49, n. 3, p. 344-361, 1997. 
GIL, Antônio Carlos. Como elaborar projetos de pesquisa. 4. ed. São Paulo: Altas, 2002, $175 \mathrm{p}$.

GODOY, Carlos Alberto de; SANTOS, Arivoaldo dos. Contabilidade para fusões e aquisições de empresas: soluções históricas para problemas contemporâneos.

Revista de Administração da Universidade de São Paulo, São Paulo, v. 41, n. 1, p. 29-42, 2006.

HARANSKY, Stephen A. Merger mania and misunderstandings: why the merger and acquisition process sometimes fails. Journal of management in engineering, [S.I.] p. 13-4, 1999.

KAYO, Eduardo Kazuo; PATROCíNIO, Mauricio Réa; MARTIN, Diogenes Manoel Leiva. Intangibilidade e criação de valor em aquisições: o papel moderador do endividamento. Revista de Administração da Universidade de São Paulo, São Paulo, v. 44, n. 1, p. 59 - 69, 2009.

KLOECKENER, Gilberto de Oliveira. Fusões e aquisições: motivos e evidência empírica. Revista de Administração, São Paulo, v. 29, n. 1, p. 42-58, 1994.

KPGM. Pesquisa de Fusões e Aquisições 2010 - 3o trimestre. 2010. Disponível em <http://www.kpmg.com.br/publicacoes_fas.asp?ft=5\&fx=5>. Acesso em: 20 nov. 2010.

LAKATOS, Eva Maria; MARCONI, Marina de Andrade. Fundamentos da metodologia científica. 3. ed. São Paulo: Altas, 1991, 270 p.

MALHOTRA, Naresh K. Pesquisa de Marketing: uma orientação aplicada. 4. ed. Porto Alegre: Bookman, 2006, 720 p.

MIRANDA, José Carlos; MARTINS, Luciano. Fusões e aquisições de empresas no Brasil. Economia e Sociedade, Campinas, n. 14, p. 67-88, 2000.

NGUYEN, Sang V.; OLLINGER, Michael. Mergers and acquisitions and productivity in the U.S. meat products industries: evidence from the micro data. Amer. J. Agr. Econ, [S.I.], v. 88, n. 3, p. 606-616, 2006.

OCDE; BID. Lei e política de concorrência no Brasil: uma revisão pelos pares, 2010.

OLIVEIRA, Oderlene Vieira de; FORTE, Sérgio Henrique Arruda Cavalcante; RAGÃO, Lindenberg Araújo. Fusões e aquisições sob a perspectiva da vantagem 
competitiva: o caso da Perdigão Agroindustrial S.A. Revista Brasileira de Gestão de Negócios, São Paulo, v. 9, n. 24, p. 91-108, 2007.

OLIVEIRA, Ualison Rébula; ROCHA, Henrique Martins. Fusões e aquisições para alavancagem de recursos e otimização da estrutura organizacional. In: SIMPÓSIO DE ENGENHARIA E PRODUÇÃO (SIMPEP), 13, 2006, Bauru.

ORSI, Ademar. Gestão do conhecimento em fusões e aquisições: fatores críticos. Revista brasileira de gestão de negócios, São Paulo, v. 8, n. 22, p. 46-56, 2006.

OZMEL. Effects of mergers and antitrust laws on merger and acquisition activity: an international analysis. In: ANNUAL MEETING OF THE AMERICAL SOCIOLOGICAL ASSOCIATION, 2006, Montreal.

PASIN, Rodrigo Maimone; MATIAS, Alberto Borges. A geração de sinergias e seus impactos na rentabilidade das empresas no caso de fusões e aquisições. Revista de Administração, São Paulo, v. 36, n. 1, p. 5-13, 2001.

PASIN, Rodrigo Maimone; MATIAS, Alberto Borges; SANTOS, Amanda G. Martins; MINADEO, Roberto. Fusões e aquisições na indústria de alimentos do Brasil: um estudo sobre a gestão financeira das empresas. Universidade de São Paulo, Ribeiro Preto, 1999.

PATROCÍNIO, Maurício Réa; KAYO, Eduardo Kazuo; KIMURA, Hebert. Intangibilidade e criação de valor nos eventos de fusão e aquisição: uma análise dos retornos anormais no período de 1994 a 2004. In: ENCONTRO NACIONAL DE PÓSGRADUAÇÃO EM ADMINISTRAÇÃO, 29, 2005, Brasília. Anais...2005.

PEREIRA, José Matias. Defesa da concorrência e regulação econômica no Brasil. Revista de Administração Mackenzie, São Paulo, v. 5, n. 1, p. 35-55, 2004.

RAVENSCRAFT, David J; SCHERER, F. M. Life after take over. The Journal of Economic Perspectives, [S.I.] v. 36, n. 2, p. 147-156, 1987.

RIBEIRO, Fernanda Cecília Ferreira; OLIVEIRA JUNIOR, Moacir de Miranda. Transferência e transferência reversa de conhecimento: o caso da aquisição da Perez Companc pela Petrobrás na Argentina. Revista Brasileira de Gestão de Negócios, São Paulo, v. 11, n. 30, p. 79-93, 2009.

ROCHA, Frederico; IOOTYY, Mariana; FERRAZ, João Carlos. Desempenho das fusões e aquisições na indústria brasileira na década de 90: a óptica das empresas adquiridas. Revista de Economia Contemporânea, Rio de Janeiro, v. 5, n. especial, p. 69-102, 2001. 
ROSS, Stephen.A; WESTERFIELD, Randolph; JAFFE, Jeffrey F. Administração Financeira: Corporate Finance. São Paulo: Atlas, 1995, 698 p.

SAMUELS, J.M; WILKES, F.M; BRAYSHAW, R.E. Management of company finance. 5 ed. London: Chapman \& Hall, 1990, 757 p.

SECRETARIA DE ACOMPANHAMENTO ECONÔMICO. Disponível em: <http://www.seae.fazenda.gov.br/>. Acesso em: 22 nov. 2010.

SILVA, Edna; MENEZES; Estera Muskat. Metodologia da pesquisa e elaboração de dissertação. 3. ed. Florianópolis: Laboratório de Ensino à Distância da UFSC, 2001, $121 \mathrm{p}$.

SUEN, Alberto Sanyuan; KIMURA, Herbert. Fusão e aquisição como estratégia de entrada (entre mode) no mercado brasileiro. Revista de Gestão da Universidade de São Paulo, São Paulo, v. 2, n. 5, p. 53-60, 1997.

TANURE, Betania; CANÇADO, Vera L. Fusões e aquisições: aprendendo com a experiência brasileira. Revista de Administração de Empresas, Rio de Janeiro, v. 45, n. 2, p. 10-22, 2005.

TEORIA DA AGÊNCIA, PROBLEMA E CUSTOS DE AGÊNCIA. Disponível em: <http://www.ibgc.org.br/PerguntasFrequentes.aspx>. Acesso em: 20 nov. 2010.

WAACK, Roberto Silva. Fusões e aquisições na indústria farmacêutico-veterinária. Revista de Gestão da Universidade de São Paulo, São Paulo, v. 7, n. 3, p. 81-98, 2000.

ZILBER, Moises Ari; FISCHMAN, Adalberto Américo; PIKIENY, Eugen Erich. Alternativa de crescimento: a alternativa de fusões e aquisições. Revista de Administração Mackenzie, São Paulo, v. 3, n. 2, p. 137-154, 2002. 


\section{APÊNDICES}

\section{Apêndice A - Dados financeiros das empresas da amostra}

\begin{tabular}{|c|c|c|c|c|c|c|c|c|c|c|c|}
\hline \multirow{2}{*}{$\begin{array}{l}\text { № do } \\
\text { processo no } \\
\text { SBCD }\end{array}$} & \multirow{2}{*}{ Empresas } & \multicolumn{2}{|c|}{ Custo da Mercadoria Vendida } & \multicolumn{2}{|c|}{ Despesas Administrativas } & \multicolumn{2}{|c|}{ Lucro Bruto } & \multicolumn{2}{|c|}{ Lucro Líquido } & \multicolumn{2}{|c|}{ Receita Líquida } \\
\hline & & 0 & +2 & 0 & +2 & 0 & +2 & 0 & +2 & 0 & +2 \\
\hline $\begin{array}{c}08012.00259 \\
1 / 2007-15\end{array}$ & $\begin{array}{c}\text { Akzo Nobel } \\
\text { N.V }\end{array}$ & 13.754 .400 .000 & 18.548 .200 .000 & 1.438 .800 .000 & 2.400 .200 .000 & 8.723 .000 .000 & 12.016 .400 .000 & 20.594 .200 .000 & 796.400 .000 & 22.477 .400 .000 & 30.564 .600 .000 \\
\hline \multirow{2}{*}{$\begin{array}{c}\text { 08012.00282 } \\
0 / 2007-93\end{array}$} & $\begin{array}{c}\text { Petróleo } \\
\text { Brasileiro S/A } \\
\text { - Petrobras }\end{array}$ & 70.444 .686 .000 & 76.096.187.000 & 4.488 .210 .000 & 5.029 .300 .000 & 56.322 .315 .000 & 57.937 .667 .000 & 22.028 .691 .000 & 29.313 .418 .000 & 126.767 .001 .000 & 134.033 .854 .000 \\
\hline & $\begin{array}{l}\text { Refinaria de } \\
\text { Petróleo } \\
\text { Ipiranga S/A }\end{array}$ & 18.224 .238 .000 & 33.412 .000 & 512.496 .000 & 1.808 .000 & 1.697.067.000 & 2.704 .000 & 181.893 .000 & 467.000 .000 & 19.921 .305 .000 & 36.116 .000 \\
\hline $\begin{array}{c}08012.00910 \\
7 / 2007-71\end{array}$ & $\begin{array}{c}\text { Hypermarcas } \\
\text { S/A }\end{array}$ & 274.616 .000 & 920.705 .000 & 36.128 .000 & 120.761 .000 & 308.260 .000 & 1.150 .057 .000 & 58.833 .000 & 313.373 .000 & 582.876 .000 & 2.070 .762 .000 \\
\hline
\end{tabular}




\begin{tabular}{|c|c|c|c|c|c|c|c|c|c|c|c|}
\hline $\begin{array}{c}08012.00946 \\
3 / 2006-11\end{array}$ & $\begin{array}{l}\text { International } \\
\text { Paper } \\
\text { Investiments }\end{array}$ & 27.394.128.000 & 31.599 .012 .000 & 3.115 .728 .000 & 3.282 .642 .000 & 9.689 .442 .000 & 10.262 .682 .000 & 1.770 .300 .000 & (2.161.452.000) & 37.083 .570 .000 & 41.861 .694 .000 \\
\hline $\begin{array}{c}08012.00946 \\
3 / 2006-11\end{array}$ & $\begin{array}{l}\text { International } \\
\text { Paper do } \\
\text { Brasil Ltda. }\end{array}$ & 27.394.128.000 & 31.599 .012 .000 & 3.115 .728 .000 & 3.282 .642 .000 & 9.689 .442 .000 & 10.262 .682 .000 & 1.770 .300 .000 & $(2.161 .452 .000)$ & 37.083 .570 .000 & 41.861 .694 .000 \\
\hline \multirow{2}{*}{$\begin{array}{c}08012.01151 \\
8 / 2006-45\end{array}$} & $\begin{array}{c}\text { Dana } \\
\text { Corporation }\end{array}$ & 13.767 .876 .000 & 11.992 .518 .000 & 706.434 .000 & 510.858 .000 & 569.868 .000 & 389.466 .000 & (1.245.954.000) & (1.131.306.000) & 14.337 .744 .000 & 12.381 .984 .000 \\
\hline & $\begin{array}{c}\text { Mahle } \\
\text { GMBH. }\end{array}$ & 7.314 .454 .400 & 8.877 .651 .200 & 435.118 .200 & 541.668 .600 & 2.176 .389 .600 & 2.152 .418 .400 & 421.986 .400 & 48.017 .200 & 9.490 .844 .000 & 11.030 .069 .600 \\
\hline $\begin{array}{c}08012.00984 \\
3 / 2005-67\end{array}$ & $\begin{array}{c}\text { Camargo } \\
\text { Corrêa } \\
\text { Cimentos S.A }\end{array}$ & 422.288 .000 & 474.825 .000 & 63.615 .000 & 52.924 .000 & 83.266 .000 & 109.353 .000 & 157.195 .000 & 211.372 .000 & 505.554 .000 & 584.178 .000 \\
\hline $\begin{array}{c}08012.01019 \\
5 / 2004-19\end{array}$ & $\begin{array}{c}\text { Suzano } \\
\text { Bahia Sul } \\
\text { Papel } \\
\text { Celulose S.A }\end{array}$ & 973.369 .000 & 1.557 .092 .000 & 152.643 .000 & 195.911 .000 & 986.794 .000 & 1.124.981.000 & 588.189 .000 & 455.314 .000 & 1.960 .163 .000 & 2.682.073.000 \\
\hline \multirow{2}{*}{$\begin{array}{c}08012.00653 \\
4 / 2003-73\end{array}$} & $\begin{array}{l}\text { Cia. Ultragaz } \\
\text { S.A. }\end{array}$ & 3.196 .445 .000 & 3.783 .420 .000 & 188.610 .000 & 232.051 .000 & 803.864 .000 & (910.428.000) & 246.379 .000 & 299.178 .000 & 4.000 .309 .000 & 4.693 .848 .000 \\
\hline & $\begin{array}{c}\text { Shell Gás } \\
\text { (LPG) Brasil } \\
\text { S.A. }\end{array}$ & 278.437.842.000 & 425.920 .692 .000 & 3.152 .820 .000 & 26.102 .652 .000 & 55.848 .750 .000 & 91.227 .774 .000 & 20.759 .718 .000 & 42.895 .212 .000 & 334.438 .332 .000 & 517.148 .466 .000 \\
\hline
\end{tabular}




\begin{tabular}{|c|c|c|c|c|c|c|c|c|c|c|c|}
\hline $\begin{array}{c}08012.00489 \\
7 / 2002-93\end{array}$ & $\begin{array}{l}\text { Companhia } \\
\text { Brasileira de } \\
\text { Distribuiçãoo }\end{array}$ & 5.820 .503 .000 & 6.272 .599 .000 & 296.284 .000 & 320.822 .000 & 2.160 .464 .000 & 2.579.938.000 & 245.122 .000 & 369.830 .000 & 7.980.967.000 & 8.852 .537 .000 \\
\hline $\begin{array}{c}08012.00489 \\
7 / 2002-93\end{array}$ & $\begin{array}{c}\text { Hermes - } \\
\text { Sociedade de } \\
\text { Investimentos } \\
\text { Mobiliários e } \\
\text { Imobiliários } \\
\text { Lda. e } \\
\text { Jerônimo } \\
\text { Martins } \\
\text { SGPS S.A. } \\
\end{array}$ & 7.442.393.200 & 6.042 .214 .200 & 327.676 .800 & 255.622 .400 & 1.119 .448 .000 & 1.645 .905 .800 & (449.629.400) & 288.039 .400 & 8.561 .841 .200 & 7.688 .120 .000 \\
\hline $\begin{array}{c}08012.00696 \\
7 / 2002-48\end{array}$ & $\begin{array}{c}\mathrm{Br} \\
\text { Participações } \\
\text { e } \\
\text { Empreendim } \\
\text { entos S.A. }\end{array}$ & 108.288 .400 .000 & 90.384 .800 .000 & 4.375 .800 .000 & 3.685 .000 .000 & 29.614.200.000 & 24.015 .200 .000 & (2.657.600.000) & (959.200.000) & 137.902 .600 .000 & 114.400 .000 .000 \\
\hline \multirow{2}{*}{$\begin{array}{c}08012.00281 \\
3 / 2007-91\end{array}$} & Braskem S/A & 10.148 .506 .000 & 11.515 .337 .000 & 545.810 .000 & 821.012 .000 & 1.985 .970 .000 & 2.388 .240 .000 & 543.220 .000 & 917.228 .000 & 12.134 .476 .000 & 13.903.577.000 \\
\hline & $\begin{array}{c}\text { Petróleo } \\
\text { Brasileiro S/A } \\
\text { - Petrobras }\end{array}$ & 70.444 .686 .000 & 76.096 .187 .000 & 4.488 .210 .000 & 5.029 .300 .000 & 56.322 .315 .000 & 57.937.667.000 & 22.028 .691 .000 & 29.313.418.000 & 126.767 .001 .000 & 134.033 .854 .000 \\
\hline \multirow{2}{*}{$\begin{array}{c}08012.00323 \\
7 / 2007-08\end{array}$} & $\begin{array}{c}\text { Dow Brasil } \\
\text { S.A }\end{array}$ & 78.065 .172 .000 & 66.003 .528 .000 & 3.137 .646 .000 & 4.193 .082 .000 & 11.925 .078 .000 & 9.655 .722 .000 & 5.032 .710 .000 & 1.139 .736 .000 & 89.990 .250 .000 & 75.659 .250 .000 \\
\hline & $\begin{array}{l}\text { Chevron } \\
\text { Phillips } \\
\text { Chemical } \\
\text { Company } \\
\text { LLC }\end{array}$ & 19.593.006.000 & 12.572.502.000 & 848.058 .000 & 826.140 .000 & 1.539 .318 .000 & 1.600 .014 .000 & 1.212 .234 .000 & 1.036 .890 .000 & 21.132 .324 .000 & 14.172.516.000 \\
\hline $\begin{array}{c}08012.00326 \\
7 / 2007-14\end{array}$ & GTI S/A & 4.938 .541 .000 & 4.697 .612 .000 & 8.436 .000 & 21.831 .000 & 9.879 .525 .000 & 1.295 .073 .000 & 272.261 .000 & 858.466 .000 & 4.940 .984 .000 & 5.992 .685 .000 \\
\hline
\end{tabular}




\begin{tabular}{|c|c|c|c|c|c|c|c|c|c|c|c|}
\hline $\begin{array}{c}08012.00330 \\
2 / 2007-97\end{array}$ & $\begin{array}{l}\text { Companhia } \\
\text { de Bebidas } \\
\text { das Américas }\end{array}$ & 4.213 .734 .000 & 4.445 .604 .000 & 1.176 .252 .000 & 1.059 .095 .000 & 7.497.228.000 & 6.753 .558 .000 & 2.816 .407 .000 & 5.959 .937 .000 & 11.710 .962 .000 & 11.199 .162 .000 \\
\hline $\begin{array}{c}08012.00530 \\
4 / 2007-11\end{array}$ & Google Inc. & 11.210 .357 .310 & 14.911 .177 .890 & 2.156 .815 .500 & 2.811 .057 .684 & 16.767.103.086 & 24.963.671.328 & 7.087.471.920 & 10.993.475.328 & 27.977.460.396 & 39.874.849.218 \\
\hline \multirow{2}{*}{$\begin{array}{c}08012.00762 \\
7 / 2007-49\end{array}$} & Barclays PLC & 2.510 .651 .000 & 3.954.922.400 & 10.718 .150 .300 & 14.393.536.300 & 58.293.692.600 & 73.575 .015 .800 & 52.296 .601 .500 & 54.488 .891 .600 & 60.804 .343 .600 & 77.529 .938 .200 \\
\hline & $\begin{array}{l}\text { ABN AMRO } \\
\text { Holding N.V. }\end{array}$ & - & - & 24.604 .800 .000 & 16.731 .000 .000 & - & - & 21.945 .000 .000 & $(9.680 .000 .000)$ & 50.014 .800 .000 & 29.249 .000 .000 \\
\hline $\begin{array}{c}08012.00886 \\
9 / 2007-50\end{array}$ & $\begin{array}{c}\text { Philips } \\
\text { Medical } \\
\text { Systems Ltda }\end{array}$ & 38.891 .600 .000 & 33.242 .000 .000 & 2.472 .800 .000 & 1.614 .800 .000 & 20.053 .000 .000 & 17.773 .800 .000 & 10.247 .600 .000 & 932.800 .000 & 58.944 .600 .000 & 51.015 .800 .000 \\
\hline $\begin{array}{c}08012.00928 \\
5 / 2007-00\end{array}$ & $\begin{array}{l}\text { Companhia } \\
\text { Providência } \\
\text { Indústria e } \\
\text { Comércio }\end{array}$ & 291.640 .000 & 211.220 .000 & 59.168 .000 & 36.387 .000 & 125.306 .000 & 140.685 .000 & 5.181 .000 & 50.986 .000 & 416.946 .000 & 351.905 .000 \\
\hline $\begin{array}{c}08012.01090 \\
3 / 2007-56\end{array}$ & $\begin{array}{l}\text { Companhia } \\
\text { Brasileira de } \\
\text { Distribuiçãa }\end{array}$ & 7.688 .807 .000 & 10.435 .484 .000 & 337.381 .000 & 481.906 .000 & 3.044 .578 .000 & 3.796 .883 .000 & 210.878 .000 & 591.580 .000 & 10.733 .385 .000 & 14.232 .367 .000 \\
\hline $\begin{array}{c}08012.01123 \\
8 / 2006-37\end{array}$ & $\begin{array}{c}\text { Americanas.c } \\
\text { om S.A. } \\
\text { Comércio } \\
\text { Eletrônico }\end{array}$ & 1.834 .177 .000 & 2.706 .419 .000 & 38.981 .000 & 48.095 .000 & 795.838 .000 & 1.226 .385 .000 & 123.521 .000 & 89.527 .000 & 2.630 .015 .000 & 3.932 .804 .000 \\
\hline
\end{tabular}




\begin{tabular}{|c|c|c|c|c|c|c|c|c|c|c|c|}
\hline $\begin{array}{l}08012.00469 \\
2 / 2005-51\end{array}$ & $\begin{array}{c}\text { Carrefour } \\
\text { Brasil } \\
\text { Comércio e } \\
\text { Indústria Ltda }\end{array}$ & 128.978 .300 .000 & 142.140 .680 .000 & 26.911.940.000 & 30.079 .940 .000 & 37.139 .520 .000 & 41.109 .860 .000 & 3.159 .200 .000 & 5.454 .240 .000 & 166.117 .820 .000 & 180.726 .700 .000 \\
\hline $\begin{array}{l}08012.00789 \\
3 / 2005-18\end{array}$ & $\begin{array}{c}\text { Americanas.c } \\
\text { om S.A.- } \\
\text { Comércio } \\
\text { Eletrônico }\end{array}$ & 1.485 .469 .000 & 2.243.450.000 & 34.052 .000 & 47.155 .000 & 646.863 .000 & 966.124 .000 & 176.148 .000 & 102.964 .000 & 2.132.332.000 & 3.209.574.000 \\
\hline \multirow{2}{*}{$\begin{array}{l}08012.00217 \\
2 / 2004-22\end{array}$} & $\begin{array}{c}\text { Braco S.A. } \\
\text { Companhia } \\
\text { de Bebidas } \\
\text { da Américas - } \\
\text { AMBEV } \\
\end{array}$ & 4.780 .500 .000 & 3.848 .894 .000 & 617.900 .000 & 912.335 .000 & 7.226 .300 .000 & 6.530 .409 .000 & 1.161 .500 .000 & 2.806.256.000 & 12.006 .800 .000 & 10.379.303.000 \\
\hline & $\begin{array}{l}\text { Interbrew } \\
\text { N.V. S/A }\end{array}$ & 8.791 .200 .000 & 12.049 .400 .000 & 1.601 .600 .000 & 2.365 .000 .000 & $(10.058 .400 .000)$ & 17.228 .200 .000 & 1.581 .800 .000 & 4.677.200.000 & 18.849 .600 .000 & 29.277 .600 .000 \\
\hline \multirow{2}{*}{$\begin{array}{l}08012.00267 \\
0 / 2004-75\end{array}$} & $\begin{array}{c}\text { United } \\
\text { Technologies } \\
\text { Corporation }\end{array}$ & 45.930 .012 .000 & 58.571 .640 .000 & 7.814 .610 .000 & 9.208 .932 .000 & $(1.741 .638 .000)$ & (790.734.000) & 4.506 .678 .000 & 6.292 .152 .000 & 44.188 .374 .000 & 57.780 .906 .000 \\
\hline & Linde Ag. & 14.385 .800 .000 & 18.803 .400 .000 & 1.590 .600 .000 & 2.098 .800 .000 & 6.340 .400 .000 & 8.562 .400 .000 & 602.800 .000 & 4.043 .600 .000 & 20.726 .200 .000 & 27.365 .800 .000 \\
\hline $\begin{array}{l}08012.00553 \\
9 / 2004-60\end{array}$ & $\begin{array}{l}\text { Petrobras } \\
\text { Distribuidora } \\
\text { S/A }\end{array}$ & 48.607 .576 .000 & 65.798 .449 .000 & 2.599.552.000 & 3.966 .866 .000 & 36.966 .859 .000 & 53.919 .351 .000 & 17.754 .171 .000 & 26.063.173.000 & 85.574 .435 .000 & 119.717 .800 .000 \\
\hline \multicolumn{2}{|c|}{$\begin{array}{l}\text { Média das empresas da } \\
\text { amostra }\end{array}$} & 31.939 .397 .086 & 37.010.301.344 & 3.261.967.223 & 4.078 .889 .485 & 13.074 .747 .803 & 15.958.797.774 & 6.206 .677 .041 & 6.147.893.244 & 45.453 .919 .548 & 52.271 .296 .743 \\
\hline
\end{tabular}


Apêndice B - Desempenho dos indicadores financeiros das empresas da amostra

\begin{tabular}{|c|c|c|c|c|c|c|c|c|c|c|c|c|}
\hline \multirow{2}{*}{ Interessados } & \multicolumn{2}{|c|}{ CMV/RL } & \multirow{2}{*}{$\begin{array}{l}\text { Variação } \\
(\%)\end{array}$} & \multicolumn{2}{|c|}{ DA/RL } & \multirow{2}{*}{$\begin{array}{c}\text { Variação } \\
(\%)\end{array}$} & \multicolumn{2}{|c|}{ MB } & \multirow{2}{*}{$\begin{array}{c}\text { Variação } \\
(\%)\end{array}$} & \multicolumn{2}{|c|}{ ML } & \multirow{2}{*}{$\begin{array}{c}\text { Variação } \\
(\%)\end{array}$} \\
\hline & 0 & +2 & & 0 & +2 & & 0 & +2 & & 0 & 2 & \\
\hline Akzo Nobel N.V & 0,61 & 0,61 & $-0,83$ & 0,06 & 0,08 & 22,68 & 0,39 & 0,39 & 1,31 & 0,92 & 0,03 & $-97,16$ \\
\hline $\begin{array}{c}\text { Petróleo Brasileiro S/A } \\
\text { - Petrobras }\end{array}$ & 0,56 & 0,57 & 2,17 & 0,04 & 0,04 & 5,98 & 0,44 & 0,43 & $-2,71$ & 0,17 & 0,22 & 25,85 \\
\hline $\begin{array}{l}\text { Refinaria de Petróleo } \\
\text { Ipiranga S/A }\end{array}$ & 0,91 & 0,93 & 1,13 & 0,03 & 0,05 & 94,59 & 0,09 & 0,07 & $-12,11$ & 0,01 & 12,93 & 141518,19 \\
\hline Hypermarcas S/A & 0,47 & 0,44 & $-5,63$ & 0,06 & 0,06 & $-5,91$ & 0,53 & 0,56 & 5,01 & 0,10 & 0,15 & 49,93 \\
\hline $\begin{array}{l}\text { International Paper } \\
\text { Investiments }\end{array}$ & 0,74 & 0,75 & 2,18 & 0,08 & 0,08 & $-6,67$ & 0,26 & 0,25 & $-6,17$ & 0,05 & $-0,05$ & $-208,16$ \\
\hline
\end{tabular}




\begin{tabular}{|c|c|c|c|c|c|c|c|c|c|c|c|c|}
\hline $\begin{array}{l}\text { International Paper do } \\
\text { Brasil Ltda. }\end{array}$ & 0,74 & 0,75 & 2,18 & 0,08 & 0,08 & $-6,67$ & 0,26 & 0,25 & $-6,17$ & 0,05 & $-0,05$ & $-208,16$ \\
\hline Dana Corporation & 0,96 & 0,97 & 0,86 & 0,05 & 0,04 & $-16,26$ & 0,04 & 0,03 & $-20,86$ & $-0,09$ & $-0,09$ & $-5,14$ \\
\hline Mahle GMBH. & 0,77 & 0,80 & 4,43 & 0,05 & 0,05 & 7,12 & 0,23 & 0,20 & $-14,90$ & 0,04 & 0,00 & $-90,21$ \\
\hline $\begin{array}{c}\text { Camargo Corrêa } \\
\text { Cimentos S.A }\end{array}$ & 0,84 & 0,81 & $-2,69$ & 0,13 & 0,09 & $-28,00$ & 0,16 & 0,19 & 13,65 & 0,31 & 0,36 & 16,37 \\
\hline $\begin{array}{l}\text { Suzano Bahia Sul } \\
\text { Papel Celulose S.A }\end{array}$ & 0,50 & 0,58 & 16,91 & 0,08 & 0,07 & $-6,20$ & 0,50 & 0,42 & $-16,68$ & 0,30 & 0,17 & $-43,43$ \\
\hline Cia. Ultragaz S.A. & 0,80 & 0,81 & 0,87 & 0,05 & 0,05 & 4,85 & 0,20 & $-0,19$ & $-196,52$ & 0,06 & 0,06 & 3,49 \\
\hline $\begin{array}{c}\text { Shell Gás (LPG) Brasil } \\
\text { S.A. }\end{array}$ & 0,83 & 0,82 & $-1,08$ & 0,01 & 0,05 & 435,41 & 0,17 & 0,18 & 5,64 & 0,06 & 0,08 & 33,63 \\
\hline $\begin{array}{c}\text { Companhia Brasileira } \\
\text { de Distribuição }\end{array}$ & 0,73 & 0,71 & $-2,84$ & 0,04 & 0,04 & $-2,38$ & 0,27 & 0,29 & 7,66 & 0,03 & 0,04 & 36,02 \\
\hline
\end{tabular}




\begin{tabular}{|c|c|c|c|c|c|c|c|c|c|c|c|c|}
\hline $\begin{array}{c}\text { Hermes - Sociedade } \\
\text { de Investimentos } \\
\text { Mobiliários e } \\
\text { Imobiliários Lda. e } \\
\text { Jerônimo Martins } \\
\text { SGPS S.A. } \\
\end{array}$ & 0,87 & 0,79 & $-9,59$ & 0,04 & 0,03 & $-13,12$ & 0,13 & 0,21 & 63,74 & $-0,05$ & 0,04 & 171,34 \\
\hline $\begin{array}{c}\text { Br Participações e } \\
\text { Empreendimentos S.A. }\end{array}$ & 0,79 & 0,79 & 0,61 & 0,03 & 0,03 & 1,51 & 0,21 & 0,21 & $-2,25$ & $-0,02$ & $-0,01$ & 56,49 \\
\hline Braskem S/A & 0,84 & 0,83 & $-0,97$ & 0,04 & 0,06 & 31,28 & 0,16 & 0,17 & 4,95 & 0,04 & 0,07 & 47,37 \\
\hline $\begin{array}{c}\text { Petróleo Brasileiro S/A } \\
\text { - Petrobras }\end{array}$ & 0,56 & 0,57 & 2,17 & 0,04 & 0,04 & 5,98 & 0,44 & 0,43 & $-2,71$ & 0,17 & 0,22 & 25,85 \\
\hline Dow Brasil S.A & 0,87 & 0,87 & 0,56 & 0,03 & 0,06 & 58,95 & 0,13 & 0,13 & $-3,69$ & 0,06 & 0,02 & $-73,06$ \\
\hline $\begin{array}{l}\text { Chevron Phillips } \\
\text { Chemical Company } \\
\text { LLC }\end{array}$ & 0,93 & 0,89 & $-4,32$ & 0,04 & 0,06 & 45,25 & 0,07 & 0,11 & 54,99 & 0,06 & 0,07 & 27,54 \\
\hline GTI S/A & 1,00 & 0,78 & $-21,57$ & 0,00 & 0,00 & 113,37 & 2,00 & 0,22 & $-89,19$ & 0,06 & 0,14 & 159,97 \\
\hline $\begin{array}{c}\text { Companhia de Bebidas } \\
\text { das Américas }\end{array}$ & 0,36 & 0,40 & 10,32 & 0,10 & 0,09 & $-5,85$ & 0,64 & 0,60 & $-5,80$ & 0,24 & 0,53 & 121,29 \\
\hline
\end{tabular}




\begin{tabular}{|c|c|c|c|c|c|c|c|c|c|c|c|c|}
\hline Google Inc. & 0,40 & 0,37 & $-6,67$ & 0,08 & 0,07 & $-8,55$ & 0,60 & 0,63 & 4,46 & 0,25 & 0,28 & 8,83 \\
\hline Barclays PLC & 0,04 & 0,05 & 23,54 & 0,18 & 0,19 & 5,32 & 0,96 & 0,95 & $-1,01$ & 0,86 & 0,70 & $-18,29$ \\
\hline $\begin{array}{c}\text { ABN AMRO Holding } \\
\text { N.V. }\end{array}$ & - & - & - & 0,49 & 0,57 & 16,28 & - & - & - & 0,44 & $-0,33$ & $-175,43$ \\
\hline $\begin{array}{l}\text { Philips Medical } \\
\text { Systems Ltda }\end{array}$ & 0,66 & 0,65 & $-1,24$ & 0,04 & 0,03 & $-24,55$ & 0,34 & 0,35 & 2,41 & 0,17 & 0,02 & $-89,48$ \\
\hline $\begin{array}{l}\text { Companhia } \\
\text { Providência Indústria e } \\
\text { Comércio }\end{array}$ & 0,70 & 0,60 & $-14,19$ & 0,14 & 0,10 & $-27,14$ & 0,30 & 0,40 & 33,02 & 0,01 & 0,14 & 1065,98 \\
\hline $\begin{array}{l}\text { Companhia Brasileira } \\
\text { de Distribuição }\end{array}$ & 0,72 & 0,73 & 2,36 & 0,03 & 0,03 & 7,72 & 0,28 & 0,27 & $-5,95$ & 0,02 & 0,04 & 111,56 \\
\hline $\begin{array}{l}\text { Americanas.com S.A. } \\
\text { Comércio Eletrônico }\end{array}$ & 0,70 & 0,69 & $-1,32$ & 0,01 & 0,01 & $-17,49$ & 0,30 & 0,31 & 3,05 & 0,05 & 0,02 & $-51,53$ \\
\hline $\begin{array}{c}\text { Carrefour Brasil } \\
\text { Comércio e Indústria } \\
\text { Ltda }\end{array}$ & 0,78 & 0,79 & 1,30 & 0,16 & 0,17 & 2,74 & 0,22 & 0,23 & 1,74 & 0,02 & 0,03 & 58,69 \\
\hline
\end{tabular}




\begin{tabular}{c|c|c|c|c|c|c|c|c|c|c|c|c}
\hline $\begin{array}{c}\text { Americanas.com S.A. - } \\
\text { Comércio Eletrônico }\end{array}$ & 0,70 & 0,70 & 0,34 & 0,02 & 0,01 & $-8,00$ & 0,30 & 0,30 & $-0,77$ & 0,08 & 0,03 & $-61,17$ \\
\hline $\begin{array}{c}\text { Braco S.A. Companhia } \\
\text { de Bebidas da } \\
\text { Américas - AMBEV }\end{array}$ & 0,40 & 0,37 & $-6,86$ & 0,05 & 0,09 & 70,80 & 0,60 & 0,63 & 4,54 & 0,10 & 0,27 & 179,49 \\
\hline $\begin{array}{c}\text { Interbrew N.V. S/A } \\
\text { Corporation }\end{array}$ & 0,47 & 0,41 & $-11,76$ & 0,08 & 0,08 & $-4,93$ & $-0,53$ & 0,59 & 10,28 & 0,08 & 0,16 & 90,37 \\
\hline $\begin{array}{c}\text { United Techolgies } \\
\text { Linde Ag. }\end{array}$ & 0,04 & 1,01 & $-2,48$ & 0,18 & 0,16 & $-9,88$ & $-0,04$ & $-0,01$ & 65,28 & 0,10 & 0,11 & 6,77 \\
\hline $\begin{array}{c}\text { Petrobras Distribuidora } \\
\text { S/A }\end{array}$ & 0,57 & 0,55 & $-3,24$ & 0,03 & 0,03 & 9,08 & 0,43 & 0,45 & 4,26 & 0,21 & 0,22 & 4,93 \\
\hline $\begin{array}{c}\text { Média das empresas } \\
\text { da amostra }\end{array}$ & 0,70 & 0,70 & $-0,82$ & 0,07 & 0,08 & 8,74 & 0,29 & 0,30 & 4,47 & 0,14 & 0,12 \\
\hline
\end{tabular}

Conclusão 